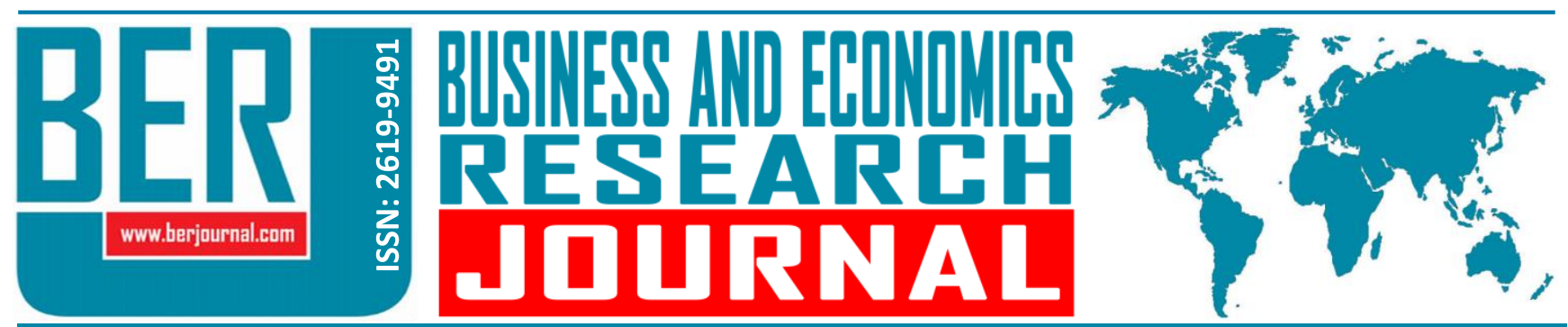

Business and Economics Research Journal Vol. 10, No. 2, 2019, pp. 415-433 doi: 10.20409/berj.2019.177

\section{Bireysel Emeklilik Şirketlerinin Entropi Ağırlıklı ARAS ve COPRAS Yöntemleri ile Karşılaştırmalı Performans Değerlendirmesi}

\author{
Eylem Bayrakci ${ }^{\mathrm{a}}$, Esra Aksoy ${ }^{\mathrm{b}}$
}

Öz: Bireysel emeklilik sistemi, bireylerin emeklilik dönemlerinde ek bir kazanç elde etmelerini sağlayarak bireylerin emeklilik dönemlerini refah içinde geçirmelerine destek olmaktadır. Bireysel emeklilik sistemi uygulandığı ülkelerde, hem sosyal güvenlik sisteminin tamamlayıcısı olarak hem de uzun vadeli yatırım fonları olarak ekonomiye katkı sağlamaktadır. Sistemde toplanan fonlar ise emeklilik branşında faaliyet göstermek üzere özel portföy yönetim şirketleri tarafından yönetilmektedir. Bu çalışmanın amacı ise ülkemizde faaliyet gösteren bireysel emeklilik şirketlerinin performansını Çok Kriterli Karar Verme yöntemlerinden ARAS ve COPRAS yöntemleri ile karşılaştırmalı olarak değerlendirmesini yapmaktır. Bireysel emeklilik şirketlerinin performans analizi için kriterler belirlenmiştir ve kriterlerin ağırlıkları entropi yöntemi ile hesaplanarak çözüme dâhil edilmiştir. Analiz sonucunda bireysel emeklilik şirketlerinin performans sıralaması yapılmıştır ve sonuç olarak her iki yöntemde sıralama aynı olarak bulunmuştur.

\section{Comparative Performance Assessment with Entropy Weighted ARAS and COPRAS Methods of Private Pension Companies}

\begin{abstract}
The individual pension system enables individuals to gain an additional income during retirement and to help individuals spend their retirement periods in welfare. In countries where the individual pension system is implemented, it contributes to the economy both as a complement to the social security system and as a long-term investment fund. The funds collected in the system are managed by private portfolio management companies to operate in the pension branch. The purpose of this study is to evaluate the performance of individual pension companies operating in our country comparatively with the ARAS and COPRAS methods of the Multi Criteria Decision Making methods. For the analysis of the performances of individual pension companies, the criteria were determined and the weights of the criteria were calculated by entropy method and included in the solution. As a result of the analysis, the performance ranking of the individual pension companies was made and as a result the ranking was found to be the same in both methods.
\end{abstract}

Anahtar Sözcükler: Bireysel Emeklilik Sistemi, Performans, Entropi, ARAS, COPRAS

JEL: G22, M20, M40

$\begin{array}{ll}\text { Geliş } & : \text { 30 Ekim } 2018 \\ \text { Düzeltme } & : \text { 31 Aralık } 2018 \\ \text { Kabul } & : 24 \text { Ocak } 2019 \\ \text { Tür } & : \text { Araştırma }\end{array}$

Keywords: Individual Pension System, Performance, Entropy, ARAS, COPRAS

JEL: G22, M20, M40
Received : 30 October 2018

Revised : 31 December 2018

Accepted : 24 January 2019

Type : Research

a Asst. Prof., PhD., Isparta University of Applied Sciences, Yalvaç Büyükkutlu School of Applied Sciences, Department of International Trade and Management, Isparta, Turkiye, eylembayrakci@isparta.edu.tr (ORCID ID: 0000-0001-8006-9160)

b Res. Asst., Suleyman Demirel University, Faculty of Economics and Administrative Sciences, Department of Banking and Finance, Isparta, Turkiye, esraaksoy@sdu.edu.tr (ORCID ID: 0000-0003-1395-2337) 


\section{Giriş}

Yaşanan teknolojik ve ekonomik gelişmelerle birlikte yaşam standardı her geçen gün artış göstermektedir. Bireyler olağan ve alıştıkları yaşam şartlarının azalmasının önüne geçerek geleceklerini garanti altına almayı, yaşlılık ve emeklilik dönemlerinde de rahat ve huzurlu bir hayat yaşamayı hedeflemektedirler. Bu istekler doğrultusunda bireyler bireysel emeklilik sistemine dâhil olarak, birikimlerini en uygun yatıım araçlarına yönlendirilmesi ile ileride istemiş oldukları hayatı ve birikimi yakalama fırsatını elde edebilmekteler (Çömlekçi ve Gökmen, 2017: 579).

Bireysel emeklilik sistemi (BES); bireylerin emeklilik zamanları geldiğinde ek bir kazanç ile bireylerin emeklilikte refah düzeyinin artmasına, iyi bir emeklilik dönemi geçirmesine olanak sağlamaktadır. Bunun yanı sıra bireysel emeklilik sistemi, ülke içinde alt yapı yatırımlarına ve uzun dönem yatırımlara fon yaratarak sistemin yeni iş gücü ve istihdam imkânları için kaynak sağlamaktadır. Aynı zamanda toplumun sosyal güvenlikten kaynaklanan yükünün en aza inmesini desteklemektedir. Sistemin işleyişi ile birlikte ekonomide uzun vadeli kaynakların elde edilmesi; enflasyonla mücadele, devamlı ve istikrarlı büyümeye olumlu katkı sağlama, spekülasyonları azaltma ve sermaye piyasasının iyi bir şekilde işlemesini sağlama gibi fonksiyonları yerine getiren özel bir emeklilik sistemidir (Altay, 2013: 125). 4632 sayılı Kanun ile birlikte yasal olarak alt yapısı hazırlanmış olan BES, mevzuat hükümlerinin düzenlenmesi ve de emeklilik şirketlerinin izin süreçlerinin sona ermesi ile 2003 yılından itibaren fiili olarak uygulanmaya konulmuştur (Inneci, 2013: 106).

Birçok gelişmiş ve gelişmekte olan ülkelerde, bireysel emeklilik sistemleri piyasalara uzun vadeli fon kaynağı olması sebebi ile ekonomik yönden büyük önem taşımaktadır. Bu nedenle BES, sosyal güvenlik sistemlerinde meydana gelen ya da meydana gelmesi muhtemel olan olumsuzlukları ortadan kaldırmanın bir aracı görevi görmektedir (Polat ve Kekeç, 2017: 177). Bununla beraber ülkelerdeki refah seviyelerindeki iyileşmeyle bireylerin yaşam sürelerinin artması, yaşlı nüfusunda görülen artışın, beraberinde sosyal güvenlik sisteminde meydana gelebilecek olası olumsuzlukların telafisi olarak görülen özel BES önemli bir yer edinmiştir (Coşkun Özer ve Gürel, 2014: 160).

Türkiye'de BES, Avrupa ve Amerika'da uygulanan sistemler göz önüne alınarak, her iki sistemde de başarılı ve pratik yönler alınarak tasarlanmıştır (İssseveroğlu ve Hatunoğlu, 2012: 156).

Genel bir ifadeyle bireylerin ortalama yaşam sürelerinde görülen artışla birlikte sosyal güvenlik sistemlerinin yükleri artma eğilimi göstermektedir. Buna karşılık, geçmiş dönemlerde meydana gelen ekonomik krizler ve bu krizlerden etkilenen ülkeler bu sebeple emeklilik sistemleri için fon ayırma hususunda sıkıntı yaşamaktadırlar. Ayrıca son dönemlerde piyasa getirileri azalış göstermekle beraber, çalışanların ödemiş oldukları prim tutarları emeklilik süresine kadar olması gereken seviyeye ulaşmamaktadır. Söz konusu sorunlarla baş edebilmek ve kalıı bir çözüm bulabilmek için çalışanlarına iş hayatı sonrasında belli bir seviyede rahatlık içinde yaşama imkânı sunmak isteyen ülkeler, devlet kaynaklı olan emeklilik sistemlerinin yükünü azaltmak ve destekler nitelikte katkı sağlayabilmek adına, özel emeklilik sistemlerine önem vermeye başlamışlardır. Ülkemizde de aynı sebeplerden dolayı özel BES uygulaması başlamıştır (Peker, 2016: 35).

BES'in amacına uygun bir şekilde işlemesi ve devam etmesi için katılımcı sayısının ve buna bağlı olarak tasarrufların arttırılması öngörülmektedir. Bu nedenle sistemin vergisel teşviklerle desteklenmesi etkili olmaktadır. Bununla birlikte özellikle inancı gereği sisteme girmek istemeyen tasarruf sahiplerini ise İslami yollara uygun olarak yatırım yapılabileceği şekilde bilgilendirilmesi sisteme olan katılımın artmasına imkân sağlayacaktır. Böylece bu uygulama gerçekleştiğinde ülkede var olan veya oluşabilecek olan fon açığının azalmasına alternatif çözüm sağlanacak ve BES'e katkı sağlayarak ekonomiye can verilmiş olacaktır (Rakıcı ve Ela, 2016: 95).

Son dönemde ise BES, ulusal tasarruf oranlarının artırılması ve ekonomiye ve sermaye piyasalarına uzun vadeli fonların kazandırıması, dış finansmana duyulan ihtiyacın azaltılması noktasında etkili olan bir uygulama olarak kullanılmaktadır. Bununla birlikte, var olan sistemin daha iyi bir seviyeye çıkarılması için gereken reformların hayata geçirilmesi için çalışmalar yapılmaktadır. Bu çalışmalar bağlamında, dünyada başarılı bir şekilde uygulanan otomatik katılım uygulamasının sisteme uyarlanması için gereken çalışmalar yürütülmüş ve bireysel emeklilik sistemine otomatik katılımı sağlayan Kanun değişikliği 01.01.2017 tarihinde 
yürürlüğe girmek üzere 2016' da TBMM'de kabul edilmiştir. Yapılacak olan bu uygulamanın orta ve uzun vadede, yurt içi tasarruf oranlarında artış göstermesine, bireylerin emeklilik dönemlerindeki alım güçlerinde yaşayabilecekleri olumsuzlukların önüne geçilmesinde ve piyasa derinliğinin artırılmasında etkili rol oynayacağını düşünülmektedir (www.egm.org.tr, BES 2016 Yılı Gelişim Raporu, 7).

Bireyleri tasarrufa yönlendirmek, yapılacak olan tasarruf hakkında bilgilendirmek ve tasarruflarını değerlendirmek için ülkemizde aktif olarak 09.03.2018 tarihi itibari ile bireysel emeklilik şirketi adı altında Emeklilik Gözetim Merkezi verilerine göre on sekiz bireysel emeklilik şirketi bulunmaktadır (www.egm.org.tr). Çalışmada söz konusu bireysel emeklilik şirketlerinin performans analizi ele alınacaktır.

Şirketlerin performans analizi olarak değerlendirmesi için birden fazla kriter açısından ele alınması gerekmektedir. Şirketlerin alternatif olarak yer alması ve birden fazla bulunması nedenleriyle şirketlerin performans analizde "Çok Kriterli Karar Verme" (ÇKKV) yöntemlerinin uygun bir seçim olabileceği görülmektedir. ÇKKV yöntemleri karmaşık bir yapı içerisinde yer alan karar verme problemlerinde alternatifler arasında karşılaştırma yapmanın zor olduğu durumlarda bu durumları en iyi şekilde belirleyerek çözüme ulaştırmaktadır. Bununla birlikte ulaştırmış olduğu çözümle karar vericiye en iyi kararı vermesine imkân sağlamaktadır. ÇKKV yöntemlerinin uygulama için seçiminde asıl amaç, çok fazla alternatif ve kriter olan problemlerde karar vericiye en iyi alternatifi belirlemek ve mümkün olduğunca hızlı bir biçimde sonuca ulaşmaktır (Urfalıŏlu ve Genç, 2013: 332). ÇKKV Yöntemleri, birçok alanda yaygın olarak kullanılmaktadır. Bu çalışmada, bireysel emeklilik şirketlerinin karşılaştırmalı performansı analizi ÇKKV yöntemlerinden ARAS ve COPRAS yöntemleri ile değerlendirilmiştir. Uygulamada ele alınan kriter ağırlıkları entropi yöntemi ile hesaplanıp her bir kriter için atanan kriter ağılıkları çözüme dahil edilmiştir. Çalışmada belirlenen kriterler doğrultusunda on sekiz bireysel emeklilik şirketi içinden en iyi alternatifi seçmek ve sıralamasını yapmaktır. Bununla birlikte birden fazla ÇKKV yöntemlerinin kullanılmasındaki amaç ise uygulamanın karşılaştırmalı olarak değerlendirilmesi ve sonucun güvenirliliğini arttırmaktır.

\section{Yazın Taraması}

ÇKKV yöntemleri, şirketlerin ve finansal sektörlerin performans değerlendirmesinde oldukça yaygın olarak kullanılan yöntemlerdir. Çalışmada kullanılan ARAS, COPRAS ve entropi yöntemleri ve bireysel emeklilik şirketlerinin performansı ile ilgili yapılan, yerli ve yabancı literatürde yer alan çalışmalardan bazıları Tablo 1'de gösterilmiştir.

Tablo 1. Entropi, ARAS ve COPRAS Yöntemleri İle Ilgili Literatür Taraması

\begin{tabular}{|l|l|}
\hline \multicolumn{2}{|c|}{ ENTROPi Yöntemi ile Yapılan Çalışmalar } \\
\hline Yeraltı Sularının Sürdürülebilirliğinin Değerlendirilmesi & Chen vd. (2015) \\
\hline Tedarikçi Seçimi & Shemshadi vd. (2011) \\
\hline Mobilya Sektörü İçin Türkiye'de Coğrafi Pazar Seçimi & Yavuz (2016) \\
\hline Otomotiv Sektöründe Faaliyette Bulunan Firmaların Performansları & Ömürbek vd. (2016) \\
\hline Petrol Şirketi Performans Değerlendirmesi & Ömürbek ve Aksoy (2016) \\
\hline OPEC Ülkelerinin Performans Değerlendirmesi Yöntemi ile Yapılan Çalışmalar \\
\hline \multicolumn{2}{|c|}{ ARAnca vd. (2016) } \\
\hline Web Sitelerinin Kalite Değerlendirmesi & Stanujkic ve Jovanovic (2012) \\
\hline Enerji Üretim Teknolojilerinin Analiz ve Seçimini & Sliogeriene vd. (2013) \\
\hline Banka Seçimi & Reza ve Majid (2013) \\
\hline İnşaat Projeleri & Lazauskas vd. (2015) \\
\hline Personel Seçimi & $\begin{array}{l}\text { Karabašević vd. (2015); Stanujkic } \\
\text { vd. (2015) }\end{array}$ \\
\hline Kurumsal Kaynak Planlaması Yazılımı Seçimi & Ecer (2016) \\
\hline Bankaların Sürdürülebilirlik Performans Değerlendirmesi & Ömürbek vd. (2017) \\
\hline Faktoring Şirketlerinin Sıralaması & Özbek ve Erol (2017) \\
\hline \multicolumn{1}{|c|}{ COPRAS Yöntemi ile Yapılan Çalışmalar } \\
\hline Proje Seçimi & Popovic vd. (2012) \\
\hline Kalite Kontrol Müdürü Seçimi & Zolfani vd. (2012) \\
\hline Materyal Seçimi & Chatterjee ve Chakraborty (2012) \\
\hline Bina Yapı Değerlendirmesi & Zolfani ve Zavadskas (2013) \\
\hline
\end{tabular}


Bireysel Emeklilik Şirketlerinin Entropi Ağırlıklı ARAS ve COPRAS Yöntemleri ile Karşılaştırmalı Performans Değerlendirmesi

\begin{tabular}{|l|l|}
\hline Sosyal Medya Platform Seçimi & Tavana vd. (2013) \\
\hline Ev Yeri Seçimi & Mulliner vd. (2013) \\
\hline Takım Tezgâhı Seçimi & Nguyen vd. (2014) \\
\hline Petrol Şirketlerin Performans Analizi & Rabbani vd. (2014) \\
\hline Türkiye Kömür İşletmelerinin Performans Değerlendirmesi & Aksoy vd. (2015) \\
\hline Firmaların Finansal Performans Analizi & Ömürbek ve Eren (2016) \\
\hline Türkiye Diyanet Vakfı'nın Performans Analizi & Özbek (2017) \\
\hline Optimal Yenilenebilir Enerji Kaynağının Tespiti & Karaca vd. (2017) \\
\hline Havalimanı Değerlendirmesi & Altın vd. (2017) \\
\hline \multicolumn{1}{|c|}{ Bireysel Emeklilik Şirketlerinin Performansı İle illgili Yapılan Çalışmalar } \\
\hline MACBETH Yöntemi İle Bireysel Emeklilik Sistemi Seçimi & Genç vd. (2015) \\
\hline $\begin{array}{l}\text { Emeklilik Yatırım Fonlarının ELECTRE I Yöntemi ile } \\
\text { Değerlendirilmesi }\end{array}$ & Ege vd. (2016) \\
\hline $\begin{array}{l}\text { Bireysel Emeklilik Planı Seçiminin COPRAS ve TOPSIS } \\
\text { Yöntemi Ille Değerlendirilmesi }\end{array}$ & Ertuğrul ve Öztaş (2016) \\
\hline $\begin{array}{l}\text { Bireysel Emeklilik Şirketlerinin ÇKKV Yöntemleriyle Hibrit Bir } \\
\text { Yaklaşımla Değerlendirilmesi }\end{array}$ & Acer ve Dinçer (2018) \\
\hline $\begin{array}{l}\text { Bireysel Emeklilik Şirketlerinin Finansal Performanslarının Bulanık } \\
\text { AHP ve VIKOR Yöntemiyle Değerlendirilmesi }\end{array}$ & Göktolga ve Karakış (2018) \\
\hline
\end{tabular}

\section{ENTROPI Yöntemi}

Entropi yazında ilk defa Rudolph Clausius (1865) tarafından tanımlanarak bir sistemde var olan düzensizliğin ve belirsizliğin ölçüsü şeklinde ifade edilmiştir (Zhang vd., 2011: 444). Ilerleyen dönemlerde ise matematik ve mühendislik alanlarında sıklıkla kullanıldığı görülen entropi kavramı Shannon (1948) ile birlikte enformasyon teorisine uyarlanmıştır. Entropi yöntemi var olan verilerin sağlamış olduğu yararlı bilginin miktarını ölçmek için kullanılmaktadır (Wu vd., 2011: 5163). Yöntem 5 adımdan oluşmaktadır ve bu adımlar sırasıyla aşağıdaki gibidir (Li vd., 2011: 2087; Wang ve Lee, 2009: 8982):

Adım 1: Karar matrisindeki her bir kriter farklı ölçü birimlerinde ise, farklı ölçü birimlerindeki aykırııkları yok etmek için standartlaştırma işlemi yapılmaktadır. Fayda ve maliyet değerlerine göre kriterler eşitlik (1) ve eşitlik (2) yardımıyla normalize edilmektedir.

$$
\begin{array}{ll}
r_{i j}=x_{i j} / \max _{i j} & (i=1 \ldots, m ; j=1, \ldots, n) \\
r_{i j}=\min _{i j} / x_{i j} & (i=1 \ldots, m ; J=1, \ldots, n)
\end{array}
$$

Adım 2: Bu adımda ise normalizasyon yapılarak $P_{i j}$ hesaplanmaktadır.

$$
P_{i j}=\frac{a_{i j}}{\sum_{i=1}^{m} a_{i j}} ; \forall j
$$

$i$ : alternatifler,

$j$ : kriterler

$P_{i j}$ : normalize edilmiş değerler

$a_{i j}$ : verilen fayda değerleri

Adım 3: Daha sonra $E_{j}^{\prime}$ nin entropisi eşitlik (4) yardımıyla hesaplanmaktadır.

$$
\begin{aligned}
& E_{j}=-k \sum_{j=1}^{m}\left[P_{i j} \ln P_{i j}\right] ; \forall_{j} \\
& k:(\ln (n))^{-1}
\end{aligned}
$$


k: entropi katsayısı

$E_{j}$ : entropi değeri

Adım 4: Ardından $d_{j}$ belirsizliği eşitlik (5) yardımıyla hesaplanır.

$$
d_{j}=1-E_{j} ; \forall_{j}
$$

Adım 5: Son adımda ise $j$ kriterinin önem derecesi olarak wj ağılıkları ise eşitlik (6) ile hesaplanır.

$$
w_{j}=\frac{d_{j}}{\sum_{j=1}^{n} d_{j}} ; \forall_{j}
$$

\section{ARAS Yöntemi}

ÇKKV yöntemlerinden biri olan ARAS (Additive Ratio Assesment) yöntemi 2010 yılında Zavadskas ve Turskis tarafından önerilmiştir (Turskis ve Zavadskas, 2010: 163). ARAS yönteminin önerilmesindeki asıl amaç, yöntemde ele alınan alternatiflerin fayda fonksiyonu değerleri, problemde uygulama yapan kişi tarafından eklenen optimal alternatife ait fayda fonksiyonu değeriyle karşılaştırmaktır (Sliogeriene vd., 2013: 13). Yöntem uygulamada yer alan tüm alternatiflerin ideal alternatife göre oransal olarak benzerliğini ortaya koymaktadır (Dadelo vd., 2012: 68). ARAS yöntemi dört adımdan oluşmaktadır ve bu adımlar aşağıdaki gibidir (Zavadskas ve Turskis, 2010: 163-165);

Adım 1: Karar matrisinin oluşturulması ile başlamaktadır. Karar matrisi oluşturulurken en üst satırda her bir kritere ait optimal değerlerden oluşan bir satır bulunmaktadır.

Karar matrisi $X$ olarak gösterilir ve;

$$
x=\left[\begin{array}{cccc}
x_{01} & x_{0 j} & \ldots & x_{o n} \\
x_{i 1} & x_{i j} & \ldots & x_{i n} \\
\ldots & \ldots & \ldots & \ldots \\
x_{m 1} & x_{m j} & \ldots & x_{m n}
\end{array}\right] \quad ; i=0,1, \ldots, m \quad j=0,1, \ldots, n
$$

$m$ : alternatif sayısını,

$n$ : kriter sayısını,

$x_{i j}:$ i. alternatifin $j$. kriterde gösterdiği performans değeri,

$x_{o j}:$ j. kriterin optimal değeridir.

Her bir kritere ait optimal değer, karar problemi için belirsiz bir durumdaysa veya bilinmiyorsa, kriterin maksimum ya da minimum özelliği göstermesine bağlı olarak optimal değer, aşağıda gösterilen eşitlik (8) ve eşitlik (9) kullanılarak hesaplanmaktadır.

$$
\begin{array}{ll}
\text { Maksimizasyon durumu: } & x_{o j}=\max _{i} x_{i j} \\
\text { Minimizasyon durumu: } & x_{o j}=\min _{i} x_{i j}
\end{array}
$$

Adım 2: Karar matrisinin normalize edilmesi ise $\bar{x}$ normalize karar matrisi $\bar{x}_{i j}$ değerlerinden oluşmaktadır. $\bar{x}_{i j}$ değerleri kriterin fayda ya da maliyet özelliği göstermesine göre iki farklı çeşit olarak hesaplanmaktadır. Kriter performans değerlerinin maksimum olması uygulama için daha iyi ise, normalize değerler eşitlik (10) kullanılarak hesaplanmaktadır. 


$$
\bar{x}_{i j}=\frac{x_{i j}}{\sum_{i=0}^{m} x_{i j}}
$$

Kriter performans değerlerinin minimum olması uygulama için daha iyi ise, normalizasyon işlemi iki adımda gerçekleştirilir. Illk olarak performans değerleri ele alınarak fayda durumuna dönüştürülür ve daha sonra normalize değerleri eşitlik (11) ve eşitlik (12) ile hesaplanır.

$$
\begin{aligned}
& x_{i j}^{*}=\frac{1}{x_{i j}} \\
& \bar{x}_{i j}=\frac{x_{i j}^{*}}{\sum_{i=0}^{m} x^{* i j}}
\end{aligned}
$$

Adım 3: Ağırlıklı normalize edilmiş karar matrisinin oluşturulması ise normalize edilmiş karar matrisi üzerinden hesaplanan $w_{i j}$ ağırlıkları kullanılarak $\hat{x}$ ağırlıklandırılmış normalize karar matrisi elde edilir. Her bir kritere atanan ağırlık değerleri $0<w_{j}<1$ koşulunu sağlamalı ve ağırlıklar toplamı 1' e eşit olmalıdır eşitlik (13).

$$
\sum_{j=1}^{n} w_{j}=1
$$

Normalize değerlerin oluşturulması için eşitlik (14) kullanılarak $\hat{x}_{i j}$ ağırlıklandırılmış normalize değerleri bulunmaktadır.

$$
\hat{x}_{i j}=\bar{x}_{i j} w_{i j}
$$

Adım 4: Optimal değerlerin hesaplanması ise, ağırlıklandııılmış karar matrisinde yer alan her bir alternatif için optimal değerler hesaplanır ve alternatiflere ait değerler eşitlik (15) kullanılarak elde edilir.

$$
S_{i}=\sum_{j=1}^{n} \hat{x}_{i j}, i=0,1, \ldots, m
$$

$S_{i}:$ i. alternatifin optimal fonksiyon değeri

Daha sonra, alternatiflere ait $S_{i}$ değerleri, $S_{0}$ optimal değerine oranlanarak $K_{i}$ fayda dereceleri eşitlik (16) kullanılarak hesaplanır.

$$
K_{i}=\frac{S_{i}}{S_{0}}, \quad i=0,1, \ldots, m
$$

Ardından $[0,1]$ aralığında değer alan $K_{i}$ oranları kullanılarak alternatiflerin fayda fonksiyonu değerleri hesaplanmaktadır ve elde edilen değerler, büyükten küçüğe doğru sıralanarak alternatiflerin sıralaması yapılmaktadır. 


\section{COPRAS Yöntemi}

Zavadskas ve Kaklauskas tarafından 1996 yılında karmaşık oransal değerlendirme COPRAS (Complex Proportional Assessment) yöntemi yeni bir ÇKKV yöntemi olarak önerilmiştir. Yöntem kriterlerin önem ve fayda dereceleri bakımından alternatiflerin sıralamasını yapmaktadır. Aynı şekilde kriter değerleri, kriter değerlendirmesinde ise maksimizasyon niteliği taşıyan kriterini üst seviyeye çıkarmakta ve minimizasyon niteliği taşıyan kriterleri en aza indirerek değerlendirilmesini yapmaktadır (Podvesko, 2011: 137).

COPRAS yönteminin diğer ÇKKV yöntemlerinden farkı ise alternatiflerin yarar derecelerini göstermesidir. Bu özelliği ile alternatiflerin birbirleriyle karşılaştırılması yapılarak diğer ele alınan alternatiflerden ne derece iyi veya derece kötü olduğunu yüzdesel olarak ifade edebilmektedir. COPRAS yöntemi 7 adımdan oluşmaktadır ve adımları aşağıdaki gibi sıralanmaktadır (Podvezko, 2011: 138-139; Zavadskas vd, 2008: 242-243; Özdağoğlu, 2013: 235-236). Yöntemde yer alan değişkenler;

$A_{j}=i$. Alternatif $\quad i=1,2, \ldots, m$

$C_{j}=j$. değerlendirme kriteri $j=1,2, \ldots ., n$

$W_{j}=j$. değerlendirme kriterinin önem düzeyi $j=1,2, \ldots, n$

$X_{i j}=j$. Değerlendirme kriteri açısından $i$. alternatifin değeridir.

Adım 1: Karar matrisinin oluşturulması ile başlamaktadır ve eşitlik (17)'deki gibi gösterilir.

$$
D=A_{3}\left[\begin{array}{ccccc}
A_{1} \\
A_{2} \\
\cdot \\
A_{m}
\end{array}\left[\begin{array}{ccccc}
x_{11} & x_{12} & x_{13} & \cdot & x_{1 n} \\
x_{21} & x_{22} & x_{23} & \cdot & x_{2 n} \\
x_{31} & x_{32} & x_{33} & \cdot & x_{3 n} \\
\cdot & \cdot & \cdot & \cdot & \cdot \\
x_{m 1} & x_{m 2} & x_{m 3} & \cdot & x_{m n}
\end{array}\right]\right.
$$

Adım 2: Normalize edilmiş karar matrisinin oluşturulması ise eşitlik (18) yardımıyla elde edilmektedir.

$$
x_{i j}^{*}=\frac{x_{i j}}{\sum_{i=1}^{m} x_{i j}} \forall j=1,2, \ldots n
$$

Adım 3: Ardından ağırıklandırılmış karar matrisinin oluşturulması için normalize edilmiş karar matrisi üzerinden her bir alternatifin kriter değeri ilgili kriter ağırlığı $w_{j}$ ile çarpılarak yani eşitlik (19) yardımı ile hesaplanmaktadır.

$$
D^{\prime}=d_{i j}=x_{i j}^{*} \cdot w_{j}
$$

Adım 4: Bu adımda ise faydalı ve faydasız kriterlerin değerleri hesaplanmaktadır. Faydalı kriterler, hedefe ulaşmada daha yüksek değerlerin daha iyi durumu gösterdiği kriterleri ifade ederken; faydasız olarak ele alınan kriterler ise hedefe ulaşmada daha düşük değerlerin daha iyi durumu gösterdiği kriterleri belirtmektedir.

$$
\begin{array}{lll}
S_{i}^{+}=\sum_{j=1}^{k} d_{i j} & j=1,2, \ldots ., k & \text { faydalı kriterler } \\
S_{i}^{-}=\sum_{j=k+1}^{n} d_{i j} & j=k+1, k+2, \ldots, n & \text { faydasız kriterler }
\end{array}
$$


Adım 5: $Q_{i}$ göreceli önem değerlerinin hesaplanmasında ise $Q_{i}$ değerleri; her bir alternatif için göreceli önem değerini verir ve eşitlik (22) kullanarak hesaplanmaktadır. Elde edilen değerler sonucu en fazla göreceli önem değerine sahip olan alternatif en iyi alternatif olarak ifade edilir.

$$
Q_{i}=S_{i}^{+}+\frac{\sum_{i=1}^{m} S_{i}^{-}}{S_{i}^{-} \cdot \sum_{i=1}^{m} \frac{1}{S_{i}^{-}}}
$$

Adım 6: En yüksek göreceli önem değerlerinin hesaplanması ise (23) numaralı eşitlik kullanılarak hesaplanmaktadır.

$$
Q_{\max }=\max \left\{Q_{i}\right\} \forall_{i}=1,2, \ldots m
$$

Adım 7: Her bir alternatif için $P_{i}$ olarak ifade edilen performans indeksi eşitlik (24) yardımıyla elde edilmektedir.

$$
P_{i}=\frac{Q_{i}}{Q_{\max }} \cdot 100 \%
$$

$P_{i}$ performans değer indeksi 100 olarak hesaplanan alternatif çözüm için en iyi alternatiftir. Son olarak tercih sıralaması yapılırken alternatiflerin almış olduğu performans indeks değerlerinin büyükten küçüğe doğru sıralaması yapılarak elde edilmektedir.

\section{Araştırma Yöntemi}

Bu çalışmada Emeklilik Gözetim Merkezi (EGM) tarafından yayınlanan ve 09.03.2018 tarihli rapordaki verilere göre şirket bazında bireysel emeklilik temel göstergeleri verileri ele alınarak, (www.egm.org.tr) bu şirketlerin performans analizi ÇKKV yöntemlerinden ARAS ve COPRAS yöntemleri ile karşılaştırmalı olarak analizi yapılacaktır. Çalışmada ARAS yönteminin tercih edilme sebebi; diğer ÇKKV yöntemlerinden farklı olarak, ARAS yönteminde alternatiflerin fayda fonksiyonu değerleri, karar problemine araştırmacı tarafından eklenen optimal alternatife ait fayda fonksiyonu değeri ile karşılaştırılmaktadır (Sliogeriene vd., 2013: 13). Yani yöntemde, her bir alternatifin ideal alternatife göre oransal benzerliği ortaya çıkarılmaktadır. Aynı zamanda çözüm aşaması oldukça basit bir yöntemdir. COPRAS yönteminin tercih edilme sebebi ise AHP ve ELECTRE gibi diğer ÇKKV yöntemleri ile karşılaştırıldığında kullanımı oldukça basit ve çözüm aşamasında hata payının düşük olmasıdır. Performans analizinde belirlenen kriterlerin ağılıkları ise entropi yöntemi ile bulunmuş ve çözüm sürecine dâhil edilmiştir. Karşılaştırmalı analiz için seçilen iki yöntemin sonuç sıralamasına bakılarak şirketler için genel bir sıralama amaçlanmıştır. Uygulamada iki yöntemin kullanılması sıralamanın güvenirliği ve sağlamlığı bakımından kontrol edilebilir özelliğe sahiptir. Bireysel Emeklilik Şirketlerinin performans analizi için ele alınan kriterler Tablo 2'de gösterildiği gibi olup, EGM sitesinin 09.03.2018 tarihli temel gösterge verilerinden elde edilmiştir.

Tablo 2. Kriterler

\begin{tabular}{|l|l|c|}
\cline { 2 - 3 } \multicolumn{1}{c|}{} & Kriterler & Kodları \\
\cline { 2 - 3 } & Katılımcı Sayısı (kişi) & K1 \\
\cline { 2 - 3 } & Katılımcıların Fon Tutarı (TL) & K2 \\
\cline { 2 - 3 } & Katkı Payı Tutarı (TL) & $\mathbf{K 4}$ \\
\hline \multirow{3}{*}{ Sözleşme ve Sertifika Sayısı (Adet) } & Bireysel Emeklilik Sözleşmeleri & $\mathbf{K 5}$ \\
\cline { 2 - 3 } & Gruba Bağlı Bireysel Emeklilik Sözleşmeleri & $\mathbf{K 6}$ \\
\cline { 2 - 3 } & İşveren Grup Emeklilik Sertifikaları & $\mathbf{K 7}$ \\
\hline \multirow{3}{*}{ Yatırıma Yönlenen Tutar (TL) } & Bireysel Emeklilik Sözleşmeleri & $\mathbf{K 8}$ \\
\cline { 2 - 3 } & Gruba Bağlı Bireysel Emeklilik Sözleşmeleri & $\mathbf{K 9}$ \\
\cline { 2 - 3 } & İşveren Grup Emeklilik Sertifikaları & $\mathbf{K 1 0}$ \\
\hline
\end{tabular}


Alternatif emeklilik şirketlerinin isimleri ve her bir emeklilik şirketi için belirlenen kodlar Tablo 3'te verilmiştir.

Tablo 3. Emeklilik Şirketleri

\begin{tabular}{|l|c|}
\hline Emeklilik Şirketleri & Kodları \\
\hline Aegon Emeklilik ve Hayat & $\mathrm{A} 1$ \\
\hline Allianz Hayat ve Emeklilik & $\mathrm{A} 2$ \\
\hline Allianz Yaşam ve Emeklilik & $\mathrm{A} 3$ \\
\hline Anadolu Hayat Emeklilik & $\mathrm{A} 4$ \\
\hline Avivasa Emeklilik ve Hayat & $\mathrm{A} 5$ \\
\hline Axa Hayat ve Emeklilik & $\mathrm{A} 6$ \\
\hline Bereket Emeklilik ve Hayat & $\mathrm{A} 7$ \\
\hline BNP Paribas Cardif Emeklilik & $\mathrm{A} 8$ \\
\hline Cigna Finans Emeklilik ve Hayat & $\mathrm{A} 9$ \\
\hline Fiba Emeklilik ve Hayat & $\mathrm{A} 10$ \\
\hline Garanti Emeklilik ve Hayat & $\mathrm{A} 11$ \\
\hline Groupama Emeklilik & $\mathrm{A} 12$ \\
\hline Halk Hayat ve Emeklilik & $\mathrm{A} 13$ \\
\hline Katılım Emeklilik ve Hayat & $\mathrm{A} 14$ \\
\hline Metlife Emeklilik ve Hayat & $\mathrm{A} 15$ \\
\hline NN Hayat ve Emeklilik & $\mathrm{A} 16$ \\
\hline Vakıf Emeklilik ve Hayat & $\mathrm{A} 17$ \\
\hline Ziraat Hayat ve Emeklilik & $\mathrm{A} 18$ \\
\hline
\end{tabular}

\subsection{ENTROPi Yöntemiyle Kriter Ağırlıklarının Hesaplanması}

Entropi yöntemi ile ağırlıklarının hesaplanması aşağıdaki adımlarla gerçekleştirilmiştir.

Adım 1: Karar matrisinin oluşturulması ile analize başlanmıştır ve elde edilen veriler aşağıda Tablo 4'te gösterildiği gibidir.

Tablo 4. Karar Matrisi

\begin{tabular}{|c|c|c|c|c|c|c|c|c|c|c|}
\hline & K1 & K2 & K3 & K4 & K5 & K6 & K7 & K8 & K9 & K10 \\
\hline A1 & 40605 & 145625964 & 101738728 & 31800 & 13680 & 857 & 79356869 & 18283796 & 1681515 & 473 \\
\hline A2 & 107486 & 2302305813 & 1686816587 & 102980 & 16804 & 4419 & 1369891013 & 253516126 & 47499945 & 3069 \\
\hline A3 & 769765 & 9555638921 & 7078289532 & 631585 & 133155 & 158667 & 4895990049 & 1499456658 & 577528885 & 8592 \\
\hline A4 & 1149274 & 12928998005 & 10022698436 & 976370 & 320915 & 34945 & 7387980342 & 2289072137 & 203793111 & 17635 \\
\hline A5 & 877902 & 13727889795 & 10579785205 & 998124 & 67413 & 46530 & 9074274590 & 953739501 & 370592901 & 13597 \\
\hline A6 & 35599 & 320063726 & 262469585 & 42454 & 1265 & 472 & 246818777 & 9557341 & 2625646 & 43 \\
\hline A7 & 108995 & 334997683 & 261982740 & 32146 & 53323 & 28637 & 110497851 & 140660681 & 8968152 & 22 \\
\hline A8 & 183291 & 1885100839 & 1478451165 & 149208 & 46609 & 25530 & 1137486589 & 259978316 & 64151485 & 1856 \\
\hline A9 & 103563 & 669935653 & 537359398 & 91688 & 17543 & 1837 & 439105045 & 83884082 & 2470379 & 99 \\
\hline A10 & 43239 & 510006963 & 433822397 & 34485 & 12712 & 4995 & 243635884 & 141233808 & 46466443 & 162 \\
\hline A11 & 1209722 & 10496207401 & 8096137882 & 1032595 & 171875 & 83447 & 6067122652 & 1616109297 & 252603199 & 9569 \\
\hline A12 & 54476 & 855834916 & 601969290 & 53367 & 7338 & 938 & 526337150 & 66898070 & 2932348 & 298 \\
\hline A13 & 508454 & 2814281383 & 2427227202 & 292704 & 227850 & 56865 & 1083280710 & 1174031322 & 148105328 & 223 \\
\hline A14 & 203779 & 897647222 & 802285703 & 170874 & 48536 & 53451 & 564952417 & 159374328 & 59413555 & 49 \\
\hline A15 & 187313 & 1360882643 & 1131338826 & 153532 & 35086 & 17168 & 795678969 & 196122562 & 124036937 & 306 \\
\hline A16 & 266229 & 2607363086 & 1977737242 & 266197 & 33438 & 10256 & 1674561053 & 244671224 & 29656108 & 3695 \\
\hline A17 & 503330 & 5332444240 & 4206708694 & 629235 & 76439 & 29788 & 3127717407 & 901389987 & 139154040 & 5876 \\
\hline A18 & 596702 & 3066061717 & 2590022668 & 405643 & 217096 & 53536 & 1542303666 & 771684560 & 241140265 & 848 \\
\hline
\end{tabular}

Adım 2: Fayda ve maliyet kriterine göre normalizasyon matrisinin oluşturulması işlemi Tablo 4'te verilen karar matrisinin normalleştirilmesi ile elde edilmiştir. Karar matrisinin normalize edilmesi ise ilk adımda Tablo 5'te gösterilen değerler eşitlik (1) yardımıyla fayda kriterleri, eşitlik (2) yardımıyla ise maliyet kriterleri hesaplanmıştır. Bireysel emeklilik sisteminde minimum 10 yıl prim ve 56 yaş şartı emeklilik için 
Bireysel Emeklilik Şirketlerinin Entropi Ağırlıklı ARAS ve COPRAS Yöntemleri ile Karşılaştırmalı Performans Değerlendirmesi

standart bir uygulamadır. Sistemden emekli olan kişi sayısının az olması gelecek dönemde sistemde kalarak prim ödemeye devam edecek kişi sayısının yüksek olacağı anlamına gelmektedir. Bu nedenle bireysel emeklilik şirketleri için emekli olan katılımcı sayısının az olması istenen bir durumdur. Bu kapsamda çalışmada, yalnızca K4 kodu ile "Emekli Olan Katılımcı Sayısı” çalışma gereği minimum kriter olarak değerlendirilmiştir ve normalize edilen karar matrisi Tablo 6'da gösterildiği gibi elde edilmiştir.

Tablo 5. Fayda ve Maliyet Kriterlerinin Hesaplanması

\begin{tabular}{|c|c|c|c|c|c|c|c|c|c|c|}
\hline & K1 & K2 & K3 & K4 & K5 & K6 & K7 & K8 & K9 & K10 \\
\hline A1 & 0,03357 & 0,010608037 & 0,009616332 & 0,0308 & 0,042628 & 0,0054 & 0,008745258 & 0,00798743 & 0,0029116 & 0,0465 \\
\hline A2 & 0,08885 & 0,167710103 & 0,159437697 & 0,09973 & 0,052363 & 0,02785 & 0,150964245 & 0,11075061 &, 0822469 & 0,0072 \\
\hline A3 & 0,63632 & 696074857 & 669039058 & 51165 & 414923 & 1 & 0,539546164 & 65504998 & 1 & 0,0026 \\
\hline A4 & 0,95003 & 0,941805201 & 0,947344227 & 0,94555 & 1 & 0,22024 & 0,814167598 & 1 & 0,3528709 & 0,0012 \\
\hline A5 & 0,72571 & 1 & 1 & 0,96662 & 0,210065 & 0,29326 & 1 & 0,41664895 & 0,6416872 & 0,0016 \\
\hline A6 & 02943 & 023314853 & 0,024808593 & 0,04111 & 0,003942 & 0,00297 & 0,027199836 & 0,0041752 & 0,0045463 & 0,5116 \\
\hline A7 & 0901 & 0,024402708 & 0,024762576 & 0,03113 & 0,166159 & 0,18048 & 0,012177045 & 0,06144878 & 0,0155285 & 1 \\
\hline A8 & & 7319054 & 9743023 & & & & 5352895 &, 11357367 & 0,1110793 & 0,0119 \\
\hline A9 & 0,08561 & 0,048801066 & 0,050791144 & 0,08879 & 0,054666 & 0,01158 & 0,048390099 & 0,03664545 & 0,0042775 & 0,2222 \\
\hline A10 & 0,03574 & 0,037151155 & 0,04100484 & 0,0334 & 0,039612 & 0,03148 & 0,026849076 & 0,06169915 & 0,0804573 & 0,1358 \\
\hline A11 & 1 & 76459001 & 0,76524596 & 1 & 0,535578 & 0,52593 & 0,6686069005 & 0,70601065 & 373863 & 0,0023 \\
\hline A12 & 0,04503 & 0,062342787 & 0,056898063 & 0,05168 & 0,022866 & 0,00591 & & 0,02922497 & 0,0050774 & 0,0738 \\
\hline A13 & 0,42031 & 0,20500466 & 0,229421217 & 0,28346 & 0,710001 & 0,35839 & 0,119379318 & 0,51288524 & 0,2564466 & 0,0987 \\
\hline A14 & 0,16845 & 0,06538858 & 0,075831946 & 0,16548 & 0,151243 & 0,33688 & 0,062258687 & 0,06962399 & 0,1028755 & 0,449 \\
\hline A15 & 0,15484 & 0,09913269 & 0,106934007 & 0,14869 & 0,109331 & 0,1082 & 0,087685132 & 0,08567776 & 0,2147718 & 0,0719 \\
\hline A16 & 0,22007 & 0,189931819 & 0,186935482 & & & 0,06464 & 0,184539385 & 0,10688664 & 0,05135 & 0,006 \\
\hline A17 & 0,41607 & 0,388438742 & 0,39761759 & 0,60937 & 0,238191 & 0,18774 & 0,344679608 & 0,39377963 & 0,2409473 & 0,0037 \\
\hline A18 & 0,49326 & 0,22334545 & 0,244808625 & 0,39284 & 0,676491 & 0,33741 & 0,169964403 & 0,33711675 & 0,417538 & 0,0259 \\
\hline$\Sigma$ & 5,74489 & 5,085361772 & 5,130240381 & 5,90259 & 4,677491 & 3,85927 & 4,448508873 & 4,70918484 & 4,0219984 & 2,6719 \\
\hline
\end{tabular}

Tablo 6. Normalize Edilmiş Karar Matrisi ( $R_{i j}$ Matrisi)

\begin{tabular}{|c|c|c|c|c|c|c|c|r|r|r|}
\cline { 2 - 11 } \multicolumn{1}{c|}{} & K1 & K2 & K3 & K4 & K5 & K6 & K7 & K8 & K9 & K10 \\
\hline A1 & 0,00584 & 0,00209 & 0,00187 & 0,00522 & 0,00911 & 0,00140 & 0,00197 & 0,00170 & 0,00072 & 0,01741 \\
\hline A2 & 0,01547 & 0,03298 & 0,03108 & 0,01690 & 0,01119 & 0,00722 & 0,03394 & 0,02352 & 0,02045 & 0,00268 \\
\hline A3 & 0,11076 & 0,13688 & 0,13041 & 0,10362 & 0,08871 & 0,25912 & 0,12129 & 0,13910 & 0,24863 & 0,00096 \\
\hline A4 & 0,16537 & 0,18520 & 0,18466 & 0,16019 & 0,21379 & 0,05707 & 0,18302 & 0,21235 & 0,08774 & 0,00047 \\
\hline A5 & 0,12632 & 0,19664 & 0,19492 & 0,16376 & 0,04491 & 0,07599 & 0,22479 & 0,08848 & 0,15954 & 0,00061 \\
\hline A6 & 0,00512 & 0,00458 & 0,00484 & 0,00697 & 0,00084 & 0,00077 & 0,00611 & 0,00089 & 0,00113 & 0,19148 \\
\hline A7 & 0,01568 & 0,00480 & 0,00483 & 0,00527 & 0,03552 & 0,04677 & 0,00274 & 0,01305 & 0,00386 & 0,37426 \\
\hline A8 & 0,02637 & 0,02700 & 0,02724 & 0,02448 & 0,03105 & 0,04169 & 0,02818 & 0,02412 & 0,02762 & 0,00444 \\
\hline A9 & 0,01490 & 0,00960 & 0,00990 & 0,01504 & 0,01169 & 0,00300 & 0,01088 & 0,00778 & 0,00106 & 0,08317 \\
\hline A10 & 0,00622 & 0,00731 & 0,00799 & 0,00566 & 0,00847 & 0,00816 & 0,00604 & 0,01310 & 0,02000 & 0,05083 \\
\hline A11 & 0,17407 & 0,15035 & 0,14916 & 0,16942 & 0,11450 & 0,13628 & 0,15030 & 0,14992 & 0,10875 & 0,00086 \\
\hline A12 & 0,00784 & 0,01226 & 0,01109 & 0,00876 & 0,00489 & 0,00153 & 0,01304 & 0,00621 & 0,00126 & 0,02763 \\
\hline A13 & 0,07316 & 0,04031 & 0,04472 & 0,04802 & 0,15179 & 0,09287 & 0,02684 & 0,10891 & 0,06376 & 0,03692 \\
\hline A14 & 0,02932 & 0,01286 & 0,01478 & 0,02804 & 0,03233 & 0,08729 & 0,01400 & 0,01478 & 0,02558 & 0,16804 \\
\hline A15 & 0,02695 & 0,01949 & 0,02084 & 0,02519 & 0,02337 & 0,02804 & 0,01971 & 0,01819 & 0,05340 & 0,02691 \\
\hline A16 & 0,03831 & 0,03735 & 0,03644 & 0,04367 & 0,02228 & 0,01675 & 0,04148 & 0,02270 & 0,01277 & 0,00223 \\
\hline A17 & 0,07242 & 0,07638 & 0,07750 & 0,10324 & 0,05092 & 0,04865 & 0,07748 & 0,08362 & 0,05991 & 0,00140 \\
\hline A18 & 0,08586 & 0,04392 & 0,04772 & 0,06655 & 0,14463 & 0,08743 & 0,03821 & 0,07159 & 0,10381 & 0,00971 \\
\hline
\end{tabular}

Adım 3: $E_{j i}$ değerinin ve $K$ değerinin hesaplanması ise, Tablo $6^{\prime}$ daki her bir kriter değerinin $\left(R_{i j}\right)$, doğal logaritma değerleri alınarak $\left(I n_{i j}\right)$, alınan logaritma değeri ile kendi değeri çarpılmıştır $\left(R_{i j} X L n_{i j}\right)$. Daha sonra Tablo 7'de bulunan her bir kritere ait değerlerin toplamları alınarak $E_{j}$ değeri eşitlik (4) yardımıyla hesaplanmıştır.

$K=1 / \ln . n 1 / \ln 18)=0,0,34597 K=1 /$ In.n, bir sabit sayı olmak üzere $0 \leq e_{i j} \leq 1$ olmasını sağlar. 
Tablo 7. Kriterlere İlişkin $R_{i j} x / n_{i j}$ Değerleri

\begin{tabular}{|c|c|c|c|c|c|c|c|c|c|c|}
\cline { 2 - 10 } \multicolumn{1}{c|}{} & K1 & K2 & K3 & K4 & K5 & K6 & K7 & K8 & K9 & K10 \\
\hline A1 & $-0,03005$ & $-0,01288$ & $-0,01177$ & $-0,02742$ & $-0,04282$ & $-0,00920$ & $-0,01225$ & $-0,01082$ & $-0,00523$ & $-0,07052$ \\
\hline A2 & $-0,06448$ & $-0,11252$ & $-0,10788$ & $-0,06895$ & $-0,05029$ & $-0,03559$ & $-0,11481$ & $-0,08819$ & $-0,07954$ & $-0,01589$ \\
\hline A3 & $-0,24372$ & $-0,27220$ & $-0,26566$ & $-0,23491$ & $-0,21488$ & $-0,34993$ & $-0,25587$ & $-0,27438$ & $-0,34604$ & $-0,00666$ \\
\hline A4 & $-0,29759$ & $-0,31231$ & $-0,31193$ & $-0,29337$ & $-0,32983$ & $-0,16342$ & $-0,31080$ & $-0,32904$ & $-0,21350$ & $-0,00358$ \\
\hline A5 & $-0,26135$ & $-0,31981$ & $-0,31873$ & $-0,29630$ & $-0,13936$ & $-0,19583$ & $-0,33552$ & $-0,21456$ & $-0,29283$ & $-0,00449$ \\
\hline A6 & $-0,02702$ & $-0,02469$ & $-0,02578$ & $-0,03460$ & $-0,00597$ & $-0,00553$ & $-0,03117$ & $-0,00623$ & $-0,00767$ & $-0,31651$ \\
\hline A7 & $-0,06517$ & $-0,02562$ & $-0,02574$ & $-0,02766$ & $-0,11856$ & $-0,14323$ & $-0,01615$ & $-0,05662$ & $-0,02145$ & $-0,36782$ \\
\hline A8 & $-0,09588$ & $-0,09753$ & $-0,09815$ & $-0,09082$ & $-0,10781$ & $-0,13248$ & $-0,10057$ & $-0,08983$ & $-0,09913$ & $-0,02404$ \\
\hline A9 & $-0,06268$ & $-0,04459$ & $-0,04569$ & $-0,06313$ & $-0,05200$ & $-0,01743$ & $-0,04918$ & $-0,03779$ & $-0,00728$ & $-0,20683$ \\
\hline A10 & $-0,03160$ & $-0,03594$ & $-0,03860$ & $-0,02928$ & $-0,04041$ & $-0,03923$ & $-0,03084$ & $-0,05680$ & $-0,07825$ & $-0,15143$ \\
\hline A11 & $-0,30432$ & $-0,28488$ & $-0,28382$ & $-0,30078$ & $-0,24814$ & $-0,27161$ & $-0,28484$ & $-0,28450$ & $-0,24128$ & $-0,00607$ \\
\hline A12 & $-0,03801$ & $-0,05396$ & $-0,04993$ & $-0,04149$ & $-0,02601$ & $-0,00993$ & $-0,05659$ & $-0,03154$ & $-0,00843$ & $-0,09916$ \\
\hline A13 & $-0,19132$ & $-0,12945$ & $-0,13896$ & $-0,14580$ & $-0,28616$ & $-0,22070$ & $-0,09709$ & $-0,24148$ & $-0,17551$ & $-0,12181$ \\
\hline A14 & $-0,10349$ & $-0,05598$ & $-0,06229$ & $-0,10021$ & $-0,11096$ & $-0,21286$ & $-0,05975$ & $-0,06231$ & $-0,09377$ & $-0,29971$ \\
\hline A15 & $-0,09740$ & $-0,07676$ & $-0,08068$ & $-0,09273$ & $-0,08780$ & $-0,10021$ & $-0,07740$ & $-0,07290$ & $-0,15646$ & $-0,09728$ \\
\hline A16 & $-0,12496$ & $-0,12278$ & $-0,12069$ & $-0,13674$ & $-0,08474$ & $-0,06849$ & $-0,13202$ & $-0,08592$ & $-0,05568$ & $-0,01361$ \\
\hline A17 & $-0,19013$ & $-0,19646$ & $-0,19821$ & $-0,23442$ & $-0,15162$ & $-0,14707$ & $-0,19818$ & $-0,20750$ & $-0,16864$ & $-0,00921$ \\
\hline A18 & $-0,21079$ & $-0,13727$ & $-0,14518$ & $-0,18034$ & $-0,27965$ & $-0,21306$ & $-0,12474$ & $-0,18876$ & $-0,23515$ & $-0,04500$ \\
\hline
\end{tabular}

Tablo 8. Kriterlere Illişkin Eij Değerleri

\begin{tabular}{|l|l|l|l|l|l|l|l|l|l|l|}
\hline $\boldsymbol{E}_{j}$ & 0,84417 & 0,80115 & 0,80602 & 0,82999 & 0,82239 & 0,80812 & 0,79151 & 0,80930 & 0,79085 & 0,64338 \\
\hline
\end{tabular}

Adım 4: $D_{i j}$ değerinin elde edilmesi için bulunan her bir $E_{i j}$ değerinden 1 çıkarılmış yani eşitlik (5) kullanılarak $D_{i j}$ değerleri hesaplanmıştır.

Tablo 9. Kriterlere İlişkin $D_{i j}$ Değerleri

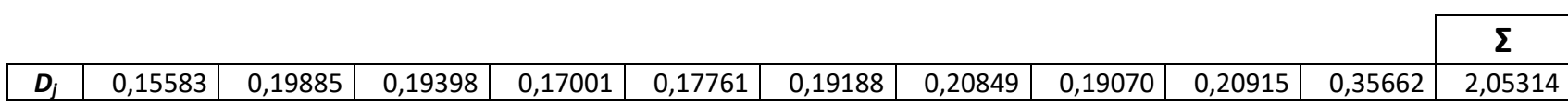

Adım 5: Kriter ağırlıklarının hesaplanması ise eşitlik (6) kullanılarak elde edilmiştir ve Tablo 10'da gösterildiği gibidir.

Tablo 10. Entropi Kriter Ağırlık Değerleri

\begin{tabular}{|c|c|c|c|c|c|c|c|c|c|c|}
\cline { 2 - 10 } \multicolumn{1}{c|}{} & K1 & K2 & K3 & K4 & K5 & K6 & K7 & K8 & K9 & K10 \\
\hline$W_{i}$ & 0,07590 & 0,09685 & 0,09448 & 0,08281 & 0,08651 & 0,09346 & 0,10155 & 0,09288 & 0,10187 & 0,17370 \\
\hline
\end{tabular}

Tabloya göre en yüksek olarak Entropi ağırlığına sahip olan kriter $(0,17370)$ indeks puanıyla; emekli olan katılımcı sayısı kriteridir. Bu kriter uygulama için en önemli performans kriteri olarak ifade edilebilir. Yatırıma yönlendirilen "bireysel emeklilik sözleşmeleri" tutarları ve "işveren grup emeklilik sertifikaları" tutarları olarak ifade edilen kriterler ise bulunan ağırlık değerleri bakımında birbirine yakın olarak ikinci en önemli kriterdir. Bununla birlikte en yüksek kriter ağırlığına sahip kriterlerin bireysel emeklilik şirketlerinin performansının belirlenmesi bakımından önde olan kriterlerdir.

\subsection{ARAS Yönteminin Uygulanması}

Adım 1: ARAS yönteminde karar matrisini oluştururken ilk satırda yer alan optimal değerler eşitlik (8) ve eşitlik (9) kullanılarak belirlenmiştir. Optimal değerler alınırken; her bir kriterin alternatif değeri için fayda kriterlerinin en yüksek değeri, minimum kriter yani çalışmada yalnızca K10 kodlu kriter için en düşük değer alınmıştır. 
Bireysel Emeklilik Şirketlerinin Entropi Ağırlıklı ARAS ve COPRAS Yöntemleri ile Karşılaştırmalı Performans Değerlendirmesi

Tablo 11. Karar Matrisi

\begin{tabular}{|c|c|c|c|c|c|c|c|c|c|c|}
\hline & K1 & K2 & K3 & K4 & K5 & K6 & K7 & K8 & K9 & K10 \\
\hline $\begin{array}{r}\text { Optimal } \\
\text { Değer }\end{array}$ & 1209722 & 13727889795 & 10579785205 & 1032595 & 320915 & 158667 & 9074274590 & 2289072137 & 577528885 & 22 \\
\hline A1 & 40605 & 145625964 & 101738728 & 31800 & 13680 & 857 & 79356869 & 18283796 & 1681515 & 473 \\
\hline A2 & 107486 & 2302305813 & 1686816587 & 102980 & 16804 & 4419 & 1369891013 & 253516126 & 47499945 & 3069 \\
\hline A3 & 769765 & 9555638921 & 7078289532 & 631585 & 133155 & 158667 & 4895990049 & 1499456658 & 577528885 & 8592 \\
\hline A4 & 1149274 & 12928998005 & 10022698436 & 976370 & 320915 & 34945 & 7387980342 & 2289072137 & 203793111 & 17635 \\
\hline A5 & 877902 & 13727889795 & 10579785205 & 998124 & 67413 & 46530 & 9074274590 & 953739501 & 370592901 & 13597 \\
\hline A6 & 35599 & 320063726 & 262469585 & 42454 & 1265 & 472 & 246818777 & 9557341 & 2625646 & 43 \\
\hline A7 & 108995 & 334997683 & 261982740 & 32146 & 53323 & 28637 & 110497851 & 140660681 & 8968152 & 22 \\
\hline A8 & 183291 & 1885100839 & 1478451165 & 149208 & 46609 & 25530 & 1137486589 & 259978316 & 64151485 & 1856 \\
\hline A9 & 103563 & 669935653 & 537359398 & 91688 & 17543 & 1837 & 439105045 & 83884082 & 2470379 & 99 \\
\hline A10 & 43239 & 510006963 & 433822397 & 34485 & 12712 & 4995 & 243635884 & 141233808 & 46466443 & 162 \\
\hline A11 & 1209722 & 10496207401 & 8096137882 & 1032595 & 171875 & 83447 & 6067122652 & 1616109297 & 252603199 & 9569 \\
\hline A12 & 54476 & 855834916 & 601969290 & 53367 & 7338 & 938 & 526337150 & 66898070 & 2932348 & 298 \\
\hline A13 & 508454 & 2814281383 & 2427227202 & 292704 & 227850 & 56865 & 1083280710 & 1174031322 & 148105328 & 223 \\
\hline A14 & 203779 & 897647222 & 802285703 & 170874 & 48536 & 53451 & 564952417 & 159374328 & 59413555 & 49 \\
\hline A15 & 187313 & 1360882643 & 1131338826 & 153532 & 35086 & 17168 & 795678969 & 196122562 & 124036937 & 306 \\
\hline A16 & 266229 & 2607363086 & 1977737242 & 266197 & 33438 & 10256 & 1674561053 & 244671224 & 29656108 & 3695 \\
\hline A17 & 503330 & 5332444240 & 4206708694 & 629235 & 76439 & 29788 & 3127717407 & 901389987 & 139154040 & 5876 \\
\hline A18 & 596702 & 3066061717 & 2590022668 & 405643 & 217096 & 53536 & 1542303666 & 771684560 & 241140265 & 848 \\
\hline
\end{tabular}

Adım 2: Bu adımda eşitlik (10) kullanılarak, kriter performans değerinin maksimum olması isteniyorsa, optimal değerlerle birlikte her bir kriterin alternatif değeri ait olduğu sütunundaki toplam değere bölünür. Eğer kriter performans değerinin minimum olması isteniyorsa, eşitlik (11) kullanılarak hesaplanan değerlerden sonra, eşitlik (12) kullanılarak yine aynı şekilde her bir kriterin alternatif değeri ait olduğu sütunundaki toplam değere bölünür.

Tablo 12. Normalize Edilmiş Karar Matrisi

\begin{tabular}{|c|c|c|c|c|c|c|c|c|c|c|}
\cline { 2 - 10 } \multicolumn{1}{c|}{} & K1 & K2 & K3 & K4 & K5 & K6 & K7 & K8 & K9 & K10 \\
\hline $\begin{array}{c}\text { Optimal } \\
\text { Değer }\end{array}$ & 0,14826 & 0,16433 & 0,16313 & 0,14487 & 0,17613 & 0,20579 & 0,18354 & 0,17516 & 0,19912 & 0,27234 \\
\hline A1 & 0,00498 & 0,00174 & 0,00157 & 0,00446 & 0,00751 & 0,00111 & 0,00161 & 0,00140 & 0,00058 & 0,01267 \\
\hline A2 & 0,01317 & 0,02756 & 0,02601 & 0,01445 & 0,00922 & 0,00573 & 0,02771 & 0,01940 & 0,01638 & 0,00195 \\
\hline A3 & 0,09434 & 0,11439 & 0,10914 & 0,08861 & 0,07308 & 0,20579 & 0,09903 & 0,11474 & 0,19912 & 0,00070 \\
\hline A4 & 0,14085 & 0,15477 & 0,15454 & 0,13698 & 0,17613 & 0,04532 & 0,14943 & 0,17516 & 0,07027 & 0,00034 \\
\hline A5 & 0,10759 & 0,16433 & 0,16313 & 0,14004 & 0,03700 & 0,06035 & 0,18354 & 0,07298 & 0,12778 & 0,00044 \\
\hline A6 & 0,00436 & 0,00383 & 0,00405 & 0,00596 & 0,00069 & 0,00061 & 0,00499 & 0,00073 & 0,00091 & 0,13934 \\
\hline A7 & 0,01336 & 0,00401 & 0,00404 & 0,00451 & 0,02927 & 0,03714 & 0,00223 & 0,01076 & 0,00309 & 0,27234 \\
\hline A8 & 0,02246 & 0,02257 & 0,02280 & 0,02093 & 0,02558 & 0,03311 & 0,02301 & 0,01989 & 0,02212 & 0,00323 \\
\hline A9 & 0,01269 & 0,00802 & 0,00829 & 0,01286 & 0,00963 & 0,00238 & 0,00888 & 0,00642 & 0,00085 & 0,06052 \\
\hline A10 & 0,00530 & 0,00611 & 0,00669 & 0,00484 & 0,00698 & 0,00648 & 0,00493 & 0,01081 & 0,01602 & 0,03698 \\
\hline A11 & 0,14826 & 0,12564 & 0,12483 & 0,14487 & 0,09433 & 0,10823 & 0,12271 & 0,12366 & 0,08709 & 0,00063 \\
\hline A12 & 0,00668 & 0,01024 & 0,00928 & 0,00749 & 0,00403 & 0,00122 & 0,01065 & 0,00512 & 0,00101 & 0,02011 \\
\hline A13 & 0,06231 & 0,03369 & 0,03742 & 0,04107 & 0,12506 & 0,07375 & 0,02191 & 0,08984 & 0,05106 & 0,02687 \\
\hline A14 & 0,02497 & 0,01075 & 0,01237 & 0,02397 & 0,02664 & 0,06933 & 0,01143 & 0,01220 & 0,02048 & 0,12227 \\
\hline A15 & 0,02296 & 0,01629 & 0,01744 & 0,02154 & 0,01926 & 0,02227 & 0,01609 & 0,01501 & 0,04277 & 0,01958 \\
\hline A16 & 0,03263 & 0,03121 & 0,03049 & 0,03735 & 0,01835 & 0,01330 & 0,03387 & 0,01872 & 0,01023 & 0,00162 \\
\hline A17 & 0,06169 & 0,06383 & 0,06486 & 0,08828 & 0,04195 & 0,03864 & 0,06326 & 0,06897 & 0,04798 & 0,00102 \\
\hline A18 & 0,07313 & 0,03670 & 0,03993 & 0,05691 & 0,11915 & 0,06944 & 0,03119 & 0,05905 & 0,08314 & 0,00707 \\
\hline
\end{tabular}

Adım 3: Ağırlıklı normalize karar matrisinin oluşturulması için eşitlik (14) ile, her bir kriterin alternatif değeri daha önceden elde edilen entropi kriter ağırlık değerleriyle çarpılarak hesaplanmıştır. 
Tablo 13. Ağırlıklandırılmış Karar Matrisi

\begin{tabular}{|c|c|c|c|c|c|c|c|c|c|c|}
\cline { 2 - 11 } \multicolumn{1}{c|}{} & K1 & K2 & K3 & K4 & K5 & K6 & K7 & K8 & K9 & K10 \\
\hline $\begin{array}{c}\text { Optimal } \\
\text { Değer }\end{array}$ & 0,01125 & 0,01592 & 0,01541 & 0,01200 & 0,01524 & 0,01923 & 0,01864 & 0,01627 & 0,02028 & 0,04730 \\
\hline A1 & 0,00038 & 0,00017 & 0,00015 & 0,00037 & 0,00065 & 0,00010 & 0,00016 & 0,00013 & 0,00006 & 0,00220 \\
\hline A2 & 0,00100 & 0,00267 & 0,00246 & 0,00120 & 0,00080 & 0,00054 & 0,00281 & 0,00180 & 0,00167 & 0,00034 \\
\hline A3 & 0,00716 & 0,01108 & 0,01031 & 0,00734 & 0,00632 & 0,01923 & 0,01006 & 0,01066 & 0,02028 & 0,00012 \\
\hline A4 & 0,01069 & 0,01499 & 0,01460 & 0,01134 & 0,01524 & 0,00424 & 0,01517 & 0,01627 & 0,00716 & 0,00006 \\
\hline A5 & 0,00817 & 0,01592 & 0,01541 & 0,01160 & 0,00320 & 0,00564 & 0,01864 & 0,00678 & 0,01302 & 0,00008 \\
\hline A6 & 0,00033 & 0,00037 & 0,00038 & 0,00049 & 0,00006 & 0,00006 & 0,00051 & 0,00007 & 0,00009 & 0,02420 \\
\hline A7 & 0,00101 & 0,00039 & 0,00038 & 0,00037 & 0,00253 & 0,00347 & 0,00023 & 0,00100 & 0,00031 & 0,04730 \\
\hline A8 & 0,00170 & 0,00219 & 0,00215 & 0,00173 & 0,00221 & 0,00309 & 0,00234 & 0,00185 & 0,00225 & 0,00056 \\
\hline A9 & 0,00096 & 0,00078 & 0,00078 & 0,00107 & 0,00083 & 0,00022 & 0,00090 & 0,00060 & 0,00009 & 0,01051 \\
\hline A10 & 0,00040 & 0,00059 & 0,00063 & 0,00040 & 0,00060 & 0,00061 & 0,00050 & 0,00100 & 0,00163 & 0,00642 \\
\hline A11 & 0,01125 & 0,01217 & 0,01179 & 0,01200 & 0,00816 & 0,01011 & 0,01246 & 0,01149 & 0,00887 & 0,00011 \\
\hline A12 & 0,00051 & 0,00099 & 0,00088 & 0,00062 & 0,00035 & 0,00011 & 0,00108 & 0,00048 & 0,00010 & 0,00349 \\
\hline A13 & 0,00473 & 0,00326 & 0,00354 & 0,00340 & 0,01082 & 0,00689 & 0,00222 & 0,00834 & 0,00520 & 0,00467 \\
\hline A14 & 0,00190 & 0,00104 & 0,00117 & 0,00199 & 0,00230 & 0,00648 & 0,00116 & 0,00113 & 0,00209 & 0,02124 \\
\hline A15 & 0,00174 & 0,00158 & 0,00165 & 0,00178 & 0,00167 & 0,00208 & 0,00163 & 0,00139 & 0,00436 & 0,00340 \\
\hline A16 & 0,00248 & 0,00302 & 0,00288 & 0,00309 & 0,00159 & 0,00124 & 0,00344 & 0,00174 & 0,00104 & 0,00028 \\
\hline A17 & 0,00468 & 0,00618 & 0,00613 & 0,00731 & 0,00363 & 0,00361 & 0,00642 & 0,00641 & 0,00489 & 0,00018 \\
\hline A18 & 0,00555 & 0,00355 & 0,00377 & 0,00471 & 0,01031 & 0,00649 & 0,00317 & 0,00548 & 0,00847 & 0,00123 \\
\hline
\end{tabular}

Adım 4: Optimallik fonksiyon değerlerinin hesaplanması için ilk olarak $S_{i}$ değerleri eşitlik (15) yardımıyla hesaplanmıştır. Ardından eşitlik (16) kullanılarak $S_{i}$ değerleri $S_{0}$ optimal değerine oranlanarak $K_{i}$ fayda dereceleri hesaplanmaktadır. Hesaplanan $K_{i}$ fayda dereceleri büyükten küçüğe doğru sıralanarak alternatifler değerlendirilmektedir.

Tablo 14. Optimallik Fonksiyon Değerleri

\begin{tabular}{|l|c|c|c|}
\cline { 2 - 4 } \multicolumn{1}{c|}{} & $\boldsymbol{\Sigma}$ & $\mathbf{K}$ & SIRALAMA \\
\hline Optimal Değer & 0,19154 & & 18 \\
\hline A1 & 0,00437 & 0,02281 & 15 \\
\hline A2 & 0,01528 & 0,07977 & 2 \\
\hline A3 & 0,10256 & 0,53545 & 1 \\
\hline A4 & 0,10976 & 0,57302 & 3 \\
\hline A5 & 0,09844 & 0,51393 & 10 \\
\hline A6 & 0,02656 & 0,13869 & 5 \\
\hline A7 & 0,05701 & 0,29762 & 13 \\
\hline A8 & 0,02008 & 0,10485 & 14 \\
\hline A9 & 0,01674 & 0,08740 & 16 \\
\hline A10 & 0,01280 & 0,06680 & 4 \\
\hline A11 & 0,09842 & 0,51381 & 17 \\
\hline A12 & 0,00861 & 0,04495 & 6 \\
\hline A13 & 0,05308 & 0,27711 & 9 \\
\hline A14 & 0,04049 & 0,21140 & 11 \\
\hline A15 & 0,02128 & 0,11112 & 12 \\
\hline A16 & 0,02081 & 0,10862 & 8 \\
\hline A17 & 0,04944 & 0,25810 & 7 \\
\hline A18 & 0,05274 & 0,27533 & \\
\hline & & & \\
\hline
\end{tabular}

ARAS yöntemi sonucu performans sıralamasına bakıldığında ilk üçte sırasıyla; A4 kodu ile Anadolu Hayat Emeklilik, A3 kodu ile Allianz Yaşam ve Emeklilik, A5 kodu ile Avivasa Emeklilik ve Hayat şirketleri yer almıştır. 


\subsection{COPRAS Yönteminin Uygulanması}

Adım 1 ve 2: Uygulama için oluşturulan karar matrisinin ardından karar matrisinin normalize edilmesiyle analize başlanmıştır. Tablo 4'teki karar matrisi eşitlik (18) kullanılarak normalize edilmiş karar matrisi oluşturulmuştur.

Tablo 15. Normalize Edilmiş Karar Matrisi

\begin{tabular}{|c|c|c|c|c|c|c|c|c|c|c|}
\cline { 2 - 11 } \multicolumn{1}{c|}{} & K1 & K2 & K3 & K4 & K5 & K6 & K7 & K8 & K9 & K10 \\
\hline A1 & 0,00584 & 0,00209 & 0,00187 & 0,00522 & 0,00911 & 0,00140 & 0,00197 & 0,00170 & 0,00072 & 0,00712 \\
\hline A2 & 0,01547 & 0,03298 & 0,03108 & 0,01690 & 0,01119 & 0,00722 & 0,03394 & 0,02352 & 0,02045 & 0,04621 \\
\hline A3 & 0,11076 & 0,13688 & 0,13041 & 0,10362 & 0,08871 & 0,25912 & 0,12129 & 0,13910 & 0,24863 & 0,12937 \\
\hline A4 & 0,16537 & 0,18520 & 0,18466 & 0,16019 & 0,21379 & 0,05707 & 0,18302 & 0,21235 & 0,08774 & 0,26554 \\
\hline A5 & 0,12632 & 0,19664 & 0,19492 & 0,16376 & 0,04491 & 0,07599 & 0,22479 & 0,08848 & 0,15954 & 0,20474 \\
\hline A6 & 0,00512 & 0,00458 & 0,00484 & 0,00697 & 0,00084 & 0,00077 & 0,00611 & 0,00089 & 0,00113 & 0,00065 \\
\hline A7 & 0,01568 & 0,00480 & 0,00483 & 0,00527 & 0,03552 & 0,04677 & 0,00274 & 0,01305 & 0,00386 & 0,00033 \\
\hline A8 & 0,02637 & 0,02700 & 0,02724 & 0,02448 & 0,03105 & 0,04169 & 0,02818 & 0,02412 & 0,02762 & 0,02795 \\
\hline A9 & 0,01490 & 0,00960 & 0,00990 & 0,01504 & 0,01169 & 0,00300 & 0,01088 & 0,00778 & 0,00106 & 0,00149 \\
\hline A10 & 0,00622 & 0,00731 & 0,00799 & 0,00566 & 0,00847 & 0,00816 & 0,00604 & 0,01310 & 0,02000 & 0,00244 \\
\hline A11 & 0,17407 & 0,15035 & 0,14916 & 0,16942 & 0,11450 & 0,13628 & 0,15030 & 0,14992 & 0,10875 & 0,14409 \\
\hline A12 & 0,00784 & 0,01226 & 0,01109 & 0,00876 & 0,00489 & 0,00153 & 0,01304 & 0,00621 & 0,00126 & 0,00449 \\
\hline A13 & 0,07316 & 0,04031 & 0,04472 & 0,04802 & 0,15179 & 0,09287 & 0,02684 & 0,10891 & 0,06376 & 0,00336 \\
\hline A14 & 0,02932 & 0,01286 & 0,01478 & 0,02804 & 0,03233 & 0,08729 & 0,01400 & 0,01478 & 0,02558 & 0,00074 \\
\hline A15 & 0,02695 & 0,01949 & 0,02084 & 0,02519 & 0,02337 & 0,02804 & 0,01971 & 0,01819 & 0,05340 & 0,00461 \\
\hline A16 & 0,03831 & 0,03735 & 0,03644 & 0,04367 & 0,02228 & 0,01675 & 0,04148 & 0,02270 & 0,01277 & 0,05564 \\
\hline A17 & 0,07242 & 0,07638 & 0,07750 & 0,10324 & 0,05092 & 0,04865 & 0,07748 & 0,08362 & 0,05991 & 0,08848 \\
\hline A18 & 0,08586 & 0,04392 & 0,04772 & 0,06655 & 0,14463 & 0,08743 & 0,03821 & 0,07159 & 0,10381 & 0,01277 \\
\hline
\end{tabular}

Adım 3: Bu adımda ağırlıklandırılmış karar matrisi; normalize edilen karar matrisi üzerinden her bir değer; her bir kriter için atanan entropi ağılıkları $(w)$ ile çarpılarak elde edilmiştir ve Tablo 16 'da gösterildiği gibidir.

Tablo 16. Ağırlıklandırılmış Karar Matrisi

\begin{tabular}{|c|c|c|c|c|c|c|c|c|c|c|}
\multicolumn{1}{c|}{} & K1 & K2 & K3 & K4 & K5 & K6 & K7 & K8 & K9 & K10 \\
\hline A1 & 0,00044 & 0,00020 & 0,00018 & 0,00043 & 0,00079 & 0,00013 & 0,00020 & 0,00016 & 0,00007 & 0,00124 \\
\hline A2 & 0,00117 & 0,00319 & 0,00294 & 0,00140 & 0,00097 & 0,00067 & 0,00345 & 0,00218 & 0,00208 & 0,00803 \\
\hline A3 & 0,00841 & 0,01326 & 0,01232 & 0,00858 & 0,00767 & 0,02422 & 0,01232 & 0,01292 & 0,02533 & 0,02247 \\
\hline A4 & 0,01255 & 0,01794 & 0,01745 & 0,01327 & 0,01849 & 0,00533 & 0,01859 & 0,01972 & 0,00894 & 0,04612 \\
\hline A5 & 0,00959 & 0,01905 & 0,01842 & 0,01356 & 0,00389 & 0,00710 & 0,02283 & 0,00822 & 0,01625 & 0,03556 \\
\hline A6 & 0,00039 & 0,00044 & 0,00046 & 0,00058 & 0,00007 & 0,00007 & 0,00062 & 0,00008 & 0,00012 & 0,00011 \\
\hline A7 & 0,00119 & 0,00046 & 0,00046 & 0,00044 & 0,00307 & 0,00437 & 0,00028 & 0,00121 & 0,00039 & 0,00006 \\
\hline A8 & 0,00200 & 0,00262 & 0,00257 & 0,00203 & 0,00269 & 0,00390 & 0,00286 & 0,00224 & 0,00281 & 0,00485 \\
\hline A9 & 0,00113 & 0,00093 & 0,00094 & 0,00125 & 0,00101 & 0,00028 & 0,00110 & 0,00072 & 0,00011 & 0,00026 \\
\hline A10 & 0,00047 & 0,00071 & 0,00076 & 0,00047 & 0,00073 & 0,00076 & 0,00061 & 0,00122 & 0,00204 & 0,00042 \\
\hline A11 & 0,01321 & 0,01456 & 0,01409 & 0,01403 & 0,00991 & 0,01274 & 0,01526 & 0,01393 & 0,01108 & 0,02503 \\
\hline A12 & 0,00059 & 0,00119 & 0,00105 & 0,00073 & 0,00042 & 0,00014 & 0,00132 & 0,00058 & 0,00013 & 0,00078 \\
\hline A13 & 0,00555 & 0,00390 & 0,00423 & 0,00398 & 0,01313 & 0,00868 & 0,00273 & 0,01012 & 0,00650 & 0,00058 \\
\hline A14 & 0,00223 & 0,00125 & 0,00140 & 0,00232 & 0,00280 & 0,00816 & 0,00142 & 0,00137 & 0,00261 & 0,00013 \\
\hline A15 & 0,00205 & 0,00189 & 0,00197 & 0,00209 & 0,00202 & 0,00262 & 0,00200 & 0,00169 & 0,00544 & 0,00080 \\
\hline A16 & 0,00291 & 0,00362 & 0,00344 & 0,00362 & 0,00193 & 0,00157 & 0,00421 & 0,00211 & 0,00130 & 0,00966 \\
\hline A17 & 0,00550 & 0,00740 & 0,00732 & 0,00855 & 0,00441 & 0,00455 & 0,00787 & 0,00777 & 0,00610 & 0,01537 \\
\hline A18 & 0,00652 & 0,00425 & 0,00451 & 0,00551 & 0,01251 & 0,00817 & 0,00388 & 0,00665 & 0,01058 & 0,00222 \\
\hline
\end{tabular}

Adım 4: Her alternatif için $S_{j}^{+}$ve $S_{j}^{-}$değerlerinin hesaplanması için eşitlik (20) kullanılarak her bir alternatif için $S_{j}^{+}$değerleri ve eşitlik (21) kullanılarak her bir alternatif için $S_{j}^{-}$değerleri hesaplanmıştır. 
Tablo 17. Alternatiflere Illişkin $S_{j}^{+}$ve $S_{j}^{-}$Değerleri

\begin{tabular}{|c|c|c|c|}
\cline { 2 - 4 } \multicolumn{1}{c|}{} & $\boldsymbol{S}_{j}^{+}$ & $\boldsymbol{S}_{j}{ }^{-}$ & $\mathbf{1} / \boldsymbol{S}_{\boldsymbol{i}}^{-}$ \\
\hline A1 & 0,00260 & 0,00124 & 808,34475 \\
\hline A2 & 0,01806 & 0,00803 & 124,58360 \\
\hline A3 & 0,12502 & 0,02247 & 44,50036 \\
\hline A4 & 0,13227 & 0,04612 & 21,68115 \\
\hline A5 & 0,11889 & 0,03556 & 28,11996 \\
\hline A6 & 0,00283 & 0,00011 & 8891,79229 \\
\hline A7 & 0,01187 & 0,00006 & 17379,41221 \\
\hline A8 & 0,02372 & 0,00485 & 206,00596 \\
\hline A9 & 0,00747 & 0,00026 & 3862,09160 \\
\hline A10 & 0,00777 & 0,00042 & 2360,16709 \\
\hline A11 & 0,11880 & 0,02503 & 39,95685 \\
\hline A12 & 0,00615 & 0,00078 & 1283,04385 \\
\hline A13 & 0,05881 & 0,00058 & 1714,56085 \\
\hline A14 & 0,02354 & 0,00013 & 7803,00140 \\
\hline A15 & 0,02176 & 0,00080 & 1249,50022 \\
\hline A16 & 0,02470 & 0,00966 & 103,47688 \\
\hline A17 & 0,05946 & 0,01537 & 65,06928 \\
\hline A18 & 0,06258 & 0,00222 & 450,88098 \\
\hline$\Sigma$ & & 0,17370 & 46436,18929 \\
\hline
\end{tabular}

Adım 5: Her alternatif için $Q_{i}$ değerlerinin hesaplanması için eşitlik (22) kullanılarak $Q_{i}$ olarak belirtilen göreceli önem değerleri hesaplanmıştır.

Tablo 18. Alternatiflere iliş̧kin $Q_{i}$ Değerleri

\begin{tabular}{|l|c|}
\cline { 2 - 2 } \multicolumn{1}{c|}{} & $\boldsymbol{Q}_{\boldsymbol{i}}$ \\
\hline A1 & 0,00563 \\
\hline A2 & 0,01853 \\
\hline A3 & 0,12519 \\
\hline A4 & 0,13236 \\
\hline A5 & 0,11900 \\
\hline A6 & 0,03609 \\
\hline A7 & 0,07688 \\
\hline A8 & 0,02449 \\
\hline A9 & 0,02191 \\
\hline A10 & 0,01659 \\
\hline A11 & 0,11895 \\
\hline A12 & 0,01095 \\
\hline A13 & 0,06522 \\
\hline A14 & 0,05273 \\
\hline A15 & 0,02644 \\
\hline A16 & 0,02508 \\
\hline A17 & 0,05970 \\
\hline A18 & 0,06426 \\
\hline
\end{tabular}

Adım 6: Her alternatif için $\mathrm{Pi}$ değerlerinin hesaplanmasında ise eşitlik (23) kullanılarak bulunan en yüksek göreceli öncelik değeri $Q_{\max }$ değeri yani 0,13236 ile eşitlik (24) kullanılarak hesaplanan her bir alternatife ait performans yüzdelik değerleri Tablo 19'daki gibi bulunmuştur. 
Tablo 19. Alternatiflere İlişkin $P_{i}$ Değerleri

\begin{tabular}{|c|c|c|}
\cline { 2 - 3 } \multicolumn{1}{c|}{} & $\boldsymbol{P}_{\boldsymbol{i}}$ & Siralama \\
\hline A1 & 4,2524384 & 18 \\
\hline A2 & 13,997032 & 15 \\
\hline A3 & 94,583214 & 2 \\
\hline A4 & 100 & 1 \\
\hline A5 & 89,908871 & 3 \\
\hline A6 & 27,26719 & 10 \\
\hline A7 & 58,087938 & 5 \\
\hline A8 & 18,500011 & 13 \\
\hline A9 & 16,557545 & 14 \\
\hline A10 & 12,537638 & 16 \\
\hline A11 & 89,872784 & 4 \\
\hline A12 & 8,2728328 & 17 \\
\hline A13 & 49,275403 & 6 \\
\hline A14 & 39,840439 & 9 \\
\hline A15 & 19,973553 & 11 \\
\hline A16 & 18,952588 & 12 \\
\hline A17 & 45,104949 & 8 \\
\hline A18 & 48,553236 & 7 \\
\hline
\end{tabular}

Bireysel emeklilik şirketlerinin performanslarının COPRAS yöntemiyle değerlendirilmesi sonucunun ARAS yöntemiyle yapılan değerlendirme ile aynı olduğu görülmektedir. Buna göre; ilk üç sırada yer alan bireysel emeklilik şirketleri sırasıyla; A4 kodu ile Anadolu Hayat Emeklilik, A3 kodu ile Allianz Yaşam ve Emeklilik, A5 kodu ile Avivasa Emeklilik ve Hayat şirketleri olmuştur.

Tablo 20. Sonuç Karşıllaştırma Tablosu

\begin{tabular}{|c|c|c|}
\cline { 2 - 3 } \multicolumn{1}{c|}{} & ARAS & COPRAS \\
\hline A1 & 18 & 18 \\
\hline A2 & 15 & 15 \\
\hline A3 & 2 & 2 \\
\hline A4 & 1 & 1 \\
\hline A5 & 3 & 3 \\
\hline A6 & 10 & 10 \\
\hline A7 & 5 & 5 \\
\hline A8 & 13 & 13 \\
\hline A9 & 14 & 14 \\
\hline A10 & 16 & 16 \\
\hline A11 & 4 & 4 \\
\hline A12 & 17 & 17 \\
\hline A13 & 6 & 6 \\
\hline A14 & 9 & 9 \\
\hline A15 & 11 & 11 \\
\hline A16 & 12 & 12 \\
\hline A17 & 8 & 8 \\
\hline A18 & 7 & 7 \\
\hline
\end{tabular}

Bireysel emeklilik şirketlerinin karşılaştırmalı performans analiz sonuçları Tablo 20' de görüldüğü gibi bulunmuştur. Her iki yöntemde de aynı sıralama elde edilmiştir. Her iki yöntemde de ilk 3 sırada yer alan BES şirketleri sırasıyla A4 koduyla Anadolu Hayat Emeklilik, A3 koduyla Allianz Yaşam ve Emeklilik ve A5 koduyla Avivasa Emeklilik ve Hayat Emeklilik şirketi yer almıştır. 


\section{Sonuç}

Bireysel emeklilik sistemi uygulandığı ülkelerde hem sosyal güvenlik sisteminin tamamlayıcısı olarak hem de uzun vadeli yatırım fonları olarak ekonomik kalkınmaya katkı sağlamaktadır. Bundan dolayı emeklilik tasarruflarının finansal piyasa sistemi içinde bulunması piyasalar için derinleştirici bir etki yaratmaktadır. Bu bağlamda emeklilik tasarrufları, bu alanda amaca uygun hizmet edebilmesi ve kullanılabilir kaynak miktarının sektör içindeki payının arttırılması için bireyleri tasarrufa yönlendirmelidir.

Bireyleri tasarrufa yönlendirmek, tasarruflar hakkında bilgilendirmek ve tasarruflarını değerlendirmek için ülkemizde bireysel emeklilik şirketi adı altında Emeklilik Gözetim Merkezi verilerine göre on sekiz bireysel emeklilik şirketi bulunmaktadır. Bu çalışmada on sekiz bireysel emeklilik şirketlerinin ÇKKV yöntemleri ile karşılaştırmalı analizi ele alınmıştır. Yapılan uygulama sonucuna bakıldığında ise hem ARAS hem COPRAS yönteminde aynı sıralamalar elde edilmiştir. Yöntemlerde sıralamanın aynı çıkması uygulamanın güvenirliğini ve alternatif sıralama doğruluğunu destekler niteliktedir. Aynı zamanda $A 4, A 3, A 5$ şirketlerinin üst sıralamada yer almasında entropi ağırlığına sahip olan kriterlerden; yatırıma yönlendirilen "bireysel emeklilik sözleşmeleri" tutarları ve "işveren grup emeklilik sertifikaları" tutarlarının etkisi bulunmaktadır. Çünkü bu şirketler belirtilen bu kriterlerde yüksek değerlere sahiptir ve bu da bireysel emeklilik şirketlerinin performansının belirlenmesinde etkili olduğunu göstermiştir. Gelecekte yapılacak çalışmalar açısından bu çalışmada ilk üç sırada yer alan şirketlerin sundukları hizmet bileşenleri değerlendirilerek şirketlerin performanslarını etkileyen nedenler araştıılabilir, ayrıca aynı çalışma uçtan uca örnekleme ile sıralamada son sıralarda yer alan şirketler ile karşılaştırılmalı olarak yapılabilir. Uygulayıcılar için ise elde edilen sonuçlar kendi şirketlerinin performanslarını görmek ve daha iyi olmak açısından yol gösterebilecektir. Aynı zamanda, araştırmanın yazın taraması bölümünde sunulduğu üzere çok kriterli karar verme yöntemleri kullanılarak bireysel emeklilik şirketlerinin performanslarını değerlendiren diğer çalışmalara; yöntem ve kullanılan kriterler açısından alternatif bir çalışma olmuştur. Bu bağlamda diğer araştırmacılara kaynak teşkil edilebileceği de düşünülmektedir.

\section{Kaynaklar}

Acer, A., \& Dinçer, E. (2018). Bireysel emeklilik şirketlerinin çok kriterli karar verme yöntemleriyle hibrit bir yaklaşımla değerlendirilmesi ve sıralanması. 19. Uluslararası EYi Sempozyumu Tam Metin Bildiri Kitabı, 17-20 Ekim, 555-569.

Aksoy, E. Ömürbek, N., \& Karaatlı, M. (2015). AHP temelli MULTIMOORA ve COPRAS yöntemi ile Türkiye Kömür İşletmeleri'nin performans değerlendirmesi. Hacettepe Üniversitesi Iktisadi ve Idari Bilimler Fakültesi Dergisi, 33(4), 1-28.

Altay, M. (2013). Türkiye'de bireysel emeklilik sistemi: Aydın ili örneği. Adnan Menderes Üniversitesi Sosyal Bilimler Enstitüsü, Yüksek Lisans Tezi, Aydın.

Altın, F. G, Karaatlı, M., \& Budak, ì. (2017). Avrupa'nın en büyük 20 havalimanının çok kriterli karar verme yöntemleri ve veri zarflama analizi ile değerlendirilmesi. Süleyman Demirel Üniversitesi Iktisadi ve Idari Bilimler Fakültesi Dergisi, 22(4), 1049-1064.

Bireysel Emeklilik $\quad$ Sistemi $2016 \quad$ Yılı $\quad$ Gelişim Raporu, http://www.egm.org.tr/bes2016gr/T\%C3\%BCrk\%C3\%A7e/BES\%20Geli\%C5\%9Fim\%20Raporu\%202016/EKitap/mobile/index.html\#p=7 (Erişim Tarihi: 09.03.2018)

Chatterjee, P., \& Chakraborty, S. (2012). Materials selection using COPRAS and COPRAS-G methods. International Journal of Materials and Structural Integrity, 6(2-4), 111-133.

Chen, J., Zhang Y., Chen Z., \& Nie, Z. (2015). Improving assessment of groundwater sustainability with analytic hierarchy process and information entropy method: A case study of the Hohhot Plain, China. Environment Earth Science, 73(5), 2353-2363.

Coşkun Özer, A., \& Gürel, H. (2014). Türkiye' de bireysel emeklilik sistemi bilgi düzeyi ve BES'e katılımda devlet katkısının etkisi üzerine bir araştırma. Mustafa Kemal Üniversitesi Sosyal Bilimler Enstitüsü Dergisi, 11(25), 159-166.

Çömlekçi, í., \& Gökmen, O. (2017). Bireysel emeklilik sistemine katılmada etkili olan faktörler: TR42 bölgesinde bir araştırma. Uluslararası Sosyal Araştırmalar Dergisi, 10(49), 579- 588. 
Dadelo, S.,Turskis, Z., Zavadskas, E., \& Dadeliene, R. (2012). Multiple criteria assessment of elite security personal on the basis of ARAS and expert methods. Economic Computation and Economic Cybernetics Studies and Research, 46(4), 65-88.

Ecer, F. (2016). ARAS yöntemi kullanılarak kurumsal kaynak planlaması yazılımı seçimi. Uluslararası Alanya işletme Fakültesi Dergisi, 8(1), 89-98.

Ege, i., Karakozak, Ö., \& Topaloğlu, E. E. (2016). Emeklilik yatırım fonlarının ELECTRE yöntemi ile performansının analizi. Finans Politik \& Ekonomik Yorumlar, 53(614), 59-68.

Ertuğrul, ì., \& Öztaş, T. (2016). Bireysel emeklilik planı seçiminde karar verme yöntemlerinin uygulanması: COPRAS ve TOPSIS Örneği. ÇKÜ Sosyal Bilimler Enstitüsü Dergisi, 7(2), 165-186.

Genç, T., Kabak, M., Köse, E., \& Yılmaz, Z. (2015). Bireysel emeklilik sistemi seçimi problemine ilişkin MACBETH yaklaşımı. Istanbul Üniversitesi Iktisat Fakültesi Ekonometri ve İstatistik Dergisi, (22), 47-65.

Göktolga, Z. G., \& Karakış, E. (2018). Bireysel emeklilik şirketlerinin finansal performanslarının bulanık AHP ve VIKOR yöntemi ile analizi. C.Ü. Iktisadi ve Idari Bilimler Dergisi, 19(1), 92-108.

İnneci, A. (2013). Bireysel emeklilik sisteminde yapılan yeni düzenlemeler ve değerlendirilmesi, Ç.Ü. Sosyal Bilimler Enstitüsü Dergisi, 22(1), 105-120.

İşseveroğlu, G., \& Hatunoğlu, Z. (2012). Türkiye'de bireysel emeklilik sisteminin makro ekonomik dinamiklere etkisi kapsamında SWOT analizi. Muhasebe ve Finansman Dergisi, Ekim, 155-174.

Karabašević, D., Stanujkić, D., \& Urošević, S. (2015). The MCDM model for personnel selection based on SWARA and ARAS methods. Management, 7, 43-52.

Karaca, C., Ulutaş, A., \& Eşgünoğlu, M. (2017). Türkiye'de optimal yenilenebilir enerji kaynağının COPRAS yöntemiyle tespiti ve yenilenebilir enerji yatırımlarının istihdam artırıcı etkisi. Maliye Dergisi, (172), 111-132.

Lazauskas, M., Kutut, V., \& Zavadskas, E. K. (2015). Multicriteria assessment of unfinished construction projects. Građevinar, 67(4), 319-328.

Li, X., Wang, K., Liu, L., Xin, J., Yang, H., \& Gao, C. (2011). Application of the entropy weight and TOPSIS method in safety evaluation of coal mines, Procedia Engineering, (26), 2085-2091.

Mulliner, E., Smallbone K., \& Maliene, V. (2013). An assessment of sustainable housing affordability using a multiple criteria decision making method. Omega, 41(2), 270- 279.

Nguyen, H., T., Dawal, S. Z. M., Nukman Y., \& Aoyama, H. (2014). A hybrid approach for fuzzy multi-attribute decision making in machine tool selection with consideration of the interactions of attributes. Expert Systems with Applications, 41(6), 3078-3090.

Ömürbek, N., \& Aksoy, E. (2016). Bir petrol şirketinin çok kriterli karar verme teknikleri ile performans değerlendirmesi. Süleyman Demirel Üniversitesi iktisadi ve Idari Bilimler Fakültesi Dergisi, 21(3), 723-756.

Ömürbek, N., \& Eren, H. (2016). PROMETHEE, MOORA ve COPRAS yöntemleri ile oran analizi sonuçlarının değerlendirilmesi: bir uygulama. Mehmet Akif Ersoy Üniversitesi Sosyal Bilimler Enstitüsü Dergisi, 8(16), 174-187.

Ömürbek, N., Karaatlı, M., \& Balcı, H. F. (2016). Entropi temelli MAUT ve SAW yöntemleri ile otomotiv firmalarının performans değerlemesi. Dokuz Eylül Üniversitesi Iktisadi ve Idari Bilimler Fakültesi Dergisi, 31(1), $227-255$.

Ömürbek, V., Aksoy, E., \& Akçakanat, Ö. (2017). Bankaların sürdürülebilirlik performanslarının ARAS, MOOSRA ve COPRAS yöntemleri ile değerlendirilmesi. Süleyman Demirel Üniversitesi Vizyoner Dergisi, 8(19), 14-32.

Özbek A., \& Erol, E. (2017). Ranking of factoring companies in accordance with ARAS and COPRAS methods. International Journal of Academic Research in Accounting, Finance and Management Sciences, 7(2), 105-116.

Özbek A. (2017). Türkiye Diyanet Vakfı'nın SAW, COPRAS ve TOPSIS yöntemi ile performans değerlendirmesi. Yönetim ve Ekonomi Araştırmaları Dergisi, 15(1), 66-84.

Özdağoğlu, A. (2013). Çok ölçütlü karar verme modellerinde normalizasyon tekniklerinin sonuçlara etkisi: COPRAS örneği. Eskişehir Osmangazi Üniversitesi iiBF Dergisi, 8(2), 229-252.

Peker, í. (2016). Türkiye'de bireysel emeklilik sistemindeki maliyetlerin düşürülmesi ve otomatik katılım sistemi üzerine öneriler. Akdeniz i.i.B.F. Dergisi, 33, 34-62.

Podvezko, V. (2011). The comparative analysis of MCDA methods SAW and COPRAS. Inzinerine Ekonomika-Engineering Economics, 22(2), 134-146.

Polat, A., \& Kekeç, H. M. (2017). Bireysel emeklilik sisteminin Türk vergi sistemi açısından analizi. Gazi Üniversitesi İktisadi ve İdari Bilimler Fakültesi Dergisi Gazi Akademi Genç Sosyal Bilimciler Sempozyumu Özel Sayısı, 175-191. 
Popovic, G., Stanujkic, D., \& Stojanovic, S. (2012). Investment project selection by applying COPRAS method and imprecise data. Serbian Journal of Management, 7(2), 257-269.

Rabbani, A., Zamani, M., Chamzini, A. Y., \& Zavadskas, E. K. (2014). Proposing a new integrated model based on sustainability balanced scorecard (SBSC) and MCDM approaches by using linguistic variables for the performance evaluation of oil producing companies. Expert Systems with Applications, 41(16), 7316-7327.

Rakıcı C., \& Ela, M. (2016). Türkiye'de bireysel emeklilik sistemine yönelik vergisel teşvikler. Abant Izzet Baysal Üniversitesi Sosyal Bilimler Enstitüsü Dergisi, 16(3), 89-110.

Reza, S., \& Majid, A. (2013). Ranking financial institutions based on of trust in online banking using ARAS and ANP method. International Research Journal of Applied and Basic Sciences, 6(4), 415-423.

Shemshadi, A., Shirazı, H., Toreihi, M., \& Tarokh, M., J. (2011). A fuzzy VIKOR method for supplier selection based on entropy measure for objective weighting. Expert Systems with Applications, (38), 12160-12167.

Sliogeriene, J., Turskis, Z., \& Streimikiene, D. (2013). Analysis and choice of energy generation technologies: the multiple criteriaaassessment on the case study of Lithuania, Energy Procedia, (32), 11-20.

Stanujkic, D., Djordjevic, B., \& Karabasevic D. (2015). Selection of candidates in the process of recruitment and selection of personnel based on the SWARA and ARAS methods. Quaestus Multidisciplinary Research Journal, (7), 53-64.

Stanujkic, D., \& Jovanovic, R. (2012). Measuring a quality of faculty website using ARAS method. Proceeding of the International Scientific Conference Contemporary Issues in Business, Management and Education, 545-554.

Tavana, M., Momeni, E., Rezaeiniya, N., Mirhedayatian, S. M. \& Rezaeiniya, H. (2013). A novel hybrid social media platform selection model using fuzzy ANP and COPRAS-G. Expert Systems with Applications, 40(14), 5694-5702.

Tunca, M. Z., Ömürbek, N., Cömert, H. G., \& Aksoy, E. (2016). OPEC ülkelerinin performanslarının çok kriterli karar verme yöntemlerinden Entropi ve MAUT ile değerlendirilmesi. Süleyman Demirel Üniversitesi Vizyoner Dergisi, 7(14), 112.

Turskis, Z., \& Zavadskas, E. K. (2010). A new additive ratio assessment (ARAS) method in multicriteria decision-making. Technological and Economic Development of Economy, (2), 159-172.

Urfalığlu, F., \& Genç, T. (2013). Çok kriterli karar verme teknikleri ile Türkiye'nin ekonomik performansının Avrupa birliği üye ülkeleri ile karşılaştırılması. Marmara Üniversitesi i.i.B. Dergisi, XXXV(II), 329-360.

Wang, T., \& Lee, H. (2009). Developing a fuzzy TOPSIS approach based on subjective weights and objective weights. Expert Systems with Applications, (36), 8980-8985.

Wu, J., Sun, J., Liang, L., \& Zha, Y. (2011). Determination of weights for ultimate cross efficiency using shannon entropy. Expert Systems with Applications, (38), 5162-5165.

Yavuz, V. A. (2016). Coğrafi pazar seçiminde PROMETHEE ve Entropi yöntemlerine dayalı çok kriterli bir analiz: mobilya sektöründe bir uygulama. Niğde Üniversitesi Iktisadi ve Idari Bilimler Fakültesi Dergisi, (92), 163-177.

Zhang, H., Gu, C., Gu, L., \& Zhang Y. (2011). The evaluation of tourism destination competitiveness by TOPSIS \& information entropy - a case in the Yangtze River Delta of China. Tourism Management, (32), 443-451.

Zolfani, S. H., Rezaeiniya, N., Aghdaie M. H., \& Zavadskas, E. K. (2012). Quality control manager selection based on AHPCOPRAS-G methods: A case in Iran. Ekonomska Istrazivanja, 25(1), 72-86.

Zolfani, S. H., \& Zavadkas, E. K. (2013). Sustainable development of rural areas' building structures based on local climate. Procedia Engineering, (57), 1295-1301.

Zavadskas, E. K., Kaklauskas, A., Turskis, Z., \& Tamosaitiene, J. (2008). Contractor selection multi attribute model applynig COPRAS method with grey interval numbers. International Conference 20th EURO Mini Conference "Continuous Optimization and Knowledge-Based Technologies" (EurOPT2008), 20-23 May, Neringa, Lithuania, 241-247.

Zavadskas, E. K., \& Turskis, Z. (2010). A new additive ratio assessment (ARAS) method in multicriteria decision-making. Technological and Economic Development of Economy, 16(2), 159-172.

Emeklilik Gözetim Merkezi, https://www.egm.org.tr/bilgi-merkezi/istatistikler/oks-istatistikleri/ (Erişim Tarihi: 05.03.2018).

07/04/2001 tarihli ve 24336 sayılı Resmi Gazete, 4632 sayılı Bireysel Emeklilik Tasarruf ve Yatırım Sistemi Kanunu 
This Page Intentionally Left Blank 